Abstract-Commercial fishermen have argued that localized concentrations of spiny dogfish (Squalus acanthias) in the northeast U.S. shelf large marine ecosystem (NES LME) have impeded their fishing operations when monitoring surveys estimated lower relative abundances. Fishery-dependent and -independent data were analyzed simultaneously to examine whether increased spatial overlap between spiny dogfish and commercial fisheries may explain high catches of this species on fishing grounds. Spatial overlap was quantified between spiny dogfish distribution and commercial fisheries from 1989 to 2009 during autumn and spring in the NES LME. Combined, the sink gillnet (SGN) and otter trawl (OT) fisheries accounted for the majority of spiny dogfish catch (autumn: 85\%; spring: $92 \%$ ), either retained (SGN) or discarded (OT). Centers of spiny dogfish abundance illustrated spatial differences in local density within the NES LME and revealed seasonal differences in spiny dogfish density. Recent increases in spatial overlap indicate that a growing portion of the spiny dogfish stock was available to each fishery over the time series. Availability, estimated as the percentage of spiny dogfish present on fishing grounds, also increased and was generally higher during autumn than spring. Abundance of mature (total length $\geq 80 \mathrm{~cm}$ ) female spiny dogfish was significantly related to availability, but trends were variable between fisheries and seasons. Although recent increases in abundance indicate recovery, research regarding the mechanisms behind these changes may help explain why abundance in the NES LME appears highly variable.

Manuscript submitted 21 November 2013. Manuscript accepted 21 January 2015. Fish. Bull. 113:101-120 (2015). doi: 10.7755/FB.113.2.1

The views and opinions expressed or implied in this article are those of the author (or authors) and do not necessarily reflect the position of the National Marine Fisheries Service, NOAA.

\title{
Spatiotemporal overlap of spiny dogfish (Squalus acanthias) and commercial fisheries in the northeast U.S. shelf large marine ecosystem
}

\author{
Skyler R. Sagarese (contact author) ${ }^{1}$ \\ Michael G. Frisk' \\ Robert M. Cerrato ${ }^{1}$ \\ Kathy A. Sosebee ${ }^{2}$ \\ John A. Musick ${ }^{3}$ \\ Paul J. Rago ${ }^{2}$
}

Email address for contact author: s.sagarese@rsmas.miami.edu

\author{
1 School of Marine and Atmospheric Sciences \\ Stony Brook University \\ Stony Brook, New York 11794-5000 \\ Present address for contact author: Cooperative Institute for Marine and Atmospheric Studies \\ Rosenstiel School of Marine and Atmospheric Sciences \\ University of Miami \\ 4600 Rickenbacker Causeway \\ Miami, Florida 33149 \\ 2 Northeast Fisheries Science Center \\ National Marine Fisheries Service, NOAA \\ 166 Water Street \\ Woods Hole, Massachusetts 02543 \\ ${ }^{3}$ Virginia Institute of Marine Science \\ College of William \& Mary \\ P.O. Box 1346 \\ Gloucester Point, Virginia 23062
}

The recent recovery, with increased abundance, of spiny dogfish (Squalus acanthias) in the late 2000 s in the northeast U.S. shelf large marine ecosystem (NES LME) is considered a success; however, it remains unclear what mechanisms are behind recent catches regarded as "unacceptably high" by fishermen (Tallack and Mandelman, 2009) and the increase in abundance observed in monitoring surveys since 2006 (Rago and Sosebee ${ }^{1}$ ). Large fluctuations in

\footnotetext{
${ }^{1}$ Rago, P. J., and K. A. Sosebee. 2013. Update on the status of spiny dogfish in 2013 and projected harvests at the Fmsy Proxy and Pstar of $40 \%$. Report to the Mid-Atlantic Fishery Management Council Scientific and Statistical Committee, 51 p. [Available at http:// www.nefsc.noaa.gov/program_review/
}

spiny dogfish abundance derived from Northeast Fisheries Science Center (NEFSC) bottom trawl surveys contrast with the expected dynamics of a species with a "slow" life history (Musick, 1999), namely late age at maturity, low fecundity, and slow growth (Nammack et al., 1985).

Spiny dogfish have experienced varying levels of exploitation since the reporting of commercial landings in the 1960s. Although foreign fishing fleets harvested substantial amounts (mean: 11,310 metric tons [t] [standard deviation (SD) 7900]) of spiny dogfish before the establishment of the U.S. Exclusive Economic

background2014/TOR3TerceiroDogfish 2013\%20 Stat $^{\circ}$ us\% 20Report\%20and\%20 Projections.pdf.] 
Zone in 1977, domestic fishery landings averaged 208 t (SD 185) (Rago and Sosebee, 2009). The majority of spiny dogfish landed during the 1970s and 1980s (mean: $4500 \mathrm{t}$ [SD 1280]) were indirectly caught by otter trawls (OT) as bycatch in groundfish and other fisheries (Rago and Sosebee, 2009). After the depletion of commercially important groundfish stocks, including the Atlantic cod (Gadus morhua) in the 1980s, a directed domestic spiny dogfish fishery commenced in 1990 (Rago et al., 1998), which predominantly used sink gillnets (SGN) to target spiny dogfish (Rago and Sosebee, 2009). Domestic landings increased substantially throughout the 1990s (mean: 18,800 t [SD 4230]) and peaked at 27,200 t in 1996 (Rago and Sosebee, 2009).

In 1998, the National Marine Fisheries Service declared the stock overfished as a result of rapid expansion of the fishery and overharvest of large fecund females (ASMFC ${ }^{2}$ ). In 1999, nearly twice as many spiny dogfish (9.3 million versus 4.6 million) were needed to match the same weight (17,000 t) landed in 1992 (Rago and Sosebee, 2009). This substantial exploitation drove recruitment to record lows between 1997 and 2003 (Rago and Sosebee, 2009), leading to implementation of regulatory measures, such as trip quotas and strict regulations, in the early 2000 s to reduce commercial harvest $\left(\mathrm{ASMFC}^{2}\right)$. The population was expected to be rebuilt by 2020 (ASMFC ${ }^{2}$ ); however, target reference points for spawning stock biomass (i.e., mature female abundance) were met in 2008 (Rago and Sosebee ${ }^{1}$ ), partly the result of an abnormally large spawning stock estimate from the bottom trawl survey conducted in spring 2006. This high estimate was the outcome of above average catches in 5 separate survey strata that may have been caused in part by dogfish schooling behavior and shifts in concentration from Southern New England and Georges Bank to the Gulf of Maine and Mid-Atlantic Bight (NEFSC $\left.{ }^{3}\right)$. This nearly 5-fold increase in estimated stock size between 2005 and 2006, however, appears biologically unrealistic given the slow life-history characteristics of the species (NEFSC ${ }^{3}$ ).

Collection of fishery-dependent data offers an inexpensive opportunity to obtain highly detailed data on commercially exploited species over large temporal and spatial scales (Bertrand et al., 2004; Hilborn, 2007). Catch per unit of effort (CPUE), an important metric derived from either fishery-dependent or fishery-independent data, is often assumed proportional to abundance (Hilborn and Walters, 1992). In nature, this assumption rarely holds because nonlinear relationships often arise between CPUE and stock abundance

\footnotetext{
${ }^{2}$ ASMFC (Atlantic States Marine Fisheries Commission). 2002. Interstate fishery management plan for spiny dogfish. Fishery Management Report No. 40, 107 p. ASMFC, Washington, D.C. [Available at http://www.asmfc.org/uploads/file/ spinyDogfishFMP.pdf.]

3 NEFSC (Northeast Fisheries Science Center). 2006. 43rd Northeast Regional Stock Assessment Workshop (43rd SAW): 43rd SAW assessment report. Northeast Fish. Sci. Cent. Ref. Doc. 06-25, 400 p. [Available from http://www.nefsc. noaa.gov/publications/crd/crd0625/.]
}

because of changes in catchability (Arreguín-Sánchez, 1996; Harley and Myers, 2001; Salthaug and Aanes, 2003).

Defined as the proportion of the population biomass caught by 1 unit of effort (Hilborn and Walters, 1992), catchability incorporates both the proportion of the stock accessible (i.e., available) and the proportion of fish in the swept volume that are caught by the gear (i.e., vulnerable) (Michalsen et al., 1996; Francis et al., 2003; Trenkel et al., 2004). The probability that an individual encountered by the gear is captured is called gear efficiency (Trenkel et al., 2004). Catchability is often parsimoniously assumed constant in both space and time (Godø, 1994; Pennington and Godø, 1995; Aglen et al., 1999) but can vary with the environment (Swain et al., 2000), fish behavior (Frisk et al., 2011), or fleet dynamics (Bertrand et al., 2004), among other factors. In particular, CPUE estimates obtained from fishery-dependent data are often discouraged as a measure for relative stock abundance. However, examination of trends from fishery-dependent data can enhance understanding of fishery distribution, fishery behavior, and fishery-fish interactions over time. For spiny dogfish, simultaneous investigation of fishery-dependent and fishery-independent information may provide critical insight into whether commercial fisheries and spiny dogfish are becoming more coincident in time and space, a potential explanation for unacceptably high catches of spiny dogfish (Tallack and Mandelman, 2009).

Survey-derived estimates of abundance provide the best available science for quantifying distribution of spiny dogfish and are used in U.S. stock assessment models to describe population dynamics. However, concerns regarding spiny dogfish availability to the NEFSC bottom trawl survey are well documented (Carlson et al., 2014; Sagarese et al., 2014a; Sagarese et al., 2014b). Complex seasonal and transboundary migratory behaviors may displace spiny dogfish outside of the survey domain (Nye et al., 2009). Further, the availability of spiny dogfish to the survey varies with environmental conditions (e.g., bottom temperature) at the time of the survey (Sagarese et al., 2014a). Relatively warmer water temperatures early in the season may cue migration earlier from southern wintering grounds (North Carolina) to northern feeding grounds (northern U.S. and Canadian waters), resulting in a greater portion of the population at the northernmost extent of the survey domain in the United States (and potential emigration into Canadian waters) (Sagarese et al., 2014a). Additionally, spiny dogfish occur south of Cape Hatteras, the southernmost point sampled by the survey, where densities may depend upon the position of the Gulf Stream (Rulifson and Moore, 2009).

This migratory behavior of spiny dogfish has resulted in a highly seasonal fishery, with fisheries generally operating in New England during the summer and off North Carolina during the winter (Camhi, 1998). In the late $1990 \mathrm{~s}$, the implementation of semiannual quota periods (period 1: May 1-Oct. 31; period 2: Nov. 1-Apr. 30) prevented southern fishermen from harvest- 
ing spiny dogfish during period 2 because the entire quota was filled during period 1 off New England.

Catchability can be affected by changes in the spatial distribution of a species on fishing grounds, either by increasing or decreasing their availability or vulnerability to the fishery (Fréon et al., 1993; Smith and Page, 1996; Godø et al., 1999). Off the coast of Peru, the catchability of Peruvian anchoveta (Engraulis ringens) changed as vulnerability increased because of high densities coupled with improved detection ability through sonar and radar (Bertrand et al., 2004). Commercial CPUE can be artificially high if fishing occurs in high-density areas because of hyperaggregation, the aggregation of fish at low abundances (Rose and Kul$\mathrm{ka}, 1999$ ). The risk of hyperaggregation is related to temporal and spatial behavior of a species and varies among species (Frisk et al., 2011).

Hyperstability can occur if CPUE remains high while stock abundance declines (Hilborn and Walters, 1992). Atlantic cod was a prime example of this concept in the late 1980s and early 1990s, when commercial CPUE remained relatively stable near the southern extent of their range while the size of the fishery footprint decreased (Hutchings, 1996; Rose and Kulka, 1999; Salthaug and Aanes, 2003). At the same time, a southward shift in distribution during the 1990s increased the vulnerability of Atlantic cod to domestic fleets within the Canadian Exclusive Economic Zone and to foreign fishing fleets outside the Canadian Exclusive Economic Zone, thereby altering its catchability (Rose et al., 1994; Rose and Kulka, 1999). For spiny dogfish, inshore shifts in population centroids during spring (males: $\sim 50 \mathrm{~km}$; females: $\sim 20 \mathrm{~km}$ ) $\left(\right.$ NEFSC $^{3}$ ) indicate that spiny dogfish may be more available to commercial fisheries that operate inshore.

Frisk et al. (2011) ranked spiny dogfish as a species of greatest concern to undergo overexploitation because of its potential for nonlinearity in survey catchability combined with a slow life history (Musick, 1999). Largescale seasonal movements and resulting distributional changes, both spatially and temporally, likely modify the availability of spiny dogfish to both the NEFSC bottom trawl survey and commercial fisheries. Changing availability to the bottom trawl survey may explain the large fluctuations in interannual abundance observed in survey estimates (Rago and Sosebee ${ }^{1}$ ). For commercial fisheries, altered availability of spiny dogfish can lead to increased bycatch and mortality if it becomes more coincident with fishing grounds.

The study described here does not attempt to address apparent increases in abundances estimated by bottom trawl surveys. Rather, we examined whether increased spatial overlap between spiny dogfish and commercial fisheries has manifested as increases in local abundance on fishing grounds-a hypothesis that has motivated a number of studies where bycatch reduction of spiny dogfish has been examined (Tallack and Mandelman, 2009; Chosid et al., 2012; O'Connell et al., 2012). The objectives of this study were 1 ) to describe the behavior of major commercial fisheries that catch spiny dogfish (either directly or indirectly as bycatch) between 1989 and 2009,2) to quantify spatial overlap and investigate spatiotemporal interactions between spiny dogfish distribution (derived from the NEFSC bottom trawl survey) and commercial fisheries (i.e., effort and catch) during this time period, and 3) to explore and relate changes in availability of spiny dogfish to catchability on commercial fishing grounds.

\section{Materials and methods}

\section{Data sources}

Fishery-dependent data Data collected by the NEFSC's large-scale Northeast Fisheries Observer Program (NEFOP) were assumed representative of commercial fishery distribution and behavior between 1989 and 2009 . Within NEFOP data, observed trips were selected carefully to ensure representation of fleet performance by season, area, and other factors (Murawski et al., 1995). At-sea sampling provided catch (total, retained, and discarded), effort, location, and associated biological and fishery data (e.g., gear) on a tow-by-tow basis with a high spatial resolution (Murawski et al., 1995).

Fishery-independent data Spiny dogfish distribution and abundance were derived from annual NEFSC bottom trawl surveys conducted with an OT during autumn and spring. These stratified random sampling surveys sample groundfish including spiny dogfish from the NES LME from Cape Hatteras, North Carolina, north to the U.S. boundary located within the Gulf of Maine (GM). Four regions were surveyed, including the GM, Georges Bank (GB), southern New England (SNE), and the Mid-Atlantic Bight. Offshore strata have been sampled during autumn since 1963 and inshore strata have been sampled during autumn since 1972, whereas the spring survey has sampled groundfish including spiny dogfish from these regions since 1968 and 1973, respectively. The number of stations sampled per stratum was proportional to its area; however, inshore strata were sampled at approximately 3 times the rate at which offshore strata were sampled. Survey design and data collection methods have remained relatively consistent throughout the time series and are detailed in Azarovitz (1981) and Azarovitz et al. ${ }^{4}$ Correction factors based on field experiments were applied for changes in vessels, gear, and doors when necessary. A transition in 2009 from the NOAA Ship Albatross IV to the NOAA Ship Henry B. Bigelow brought about changes to the trawling gear and survey protocol (Brown et al. ${ }^{5}$ )

\footnotetext{
${ }^{4}$ Azarovitz, T., S. Clark, L. Despres, and C. J. Byrne. 1997. The Northeast Fisheries Science Center bottom trawl survey programme. ICES Committee Meeting (C.M.) document 1997/Y:33, 21 p.

${ }^{5}$ Brown, R. W., M. Fogarty, C. Legault, T. Miller, V. Nordahl, P. Politis, and P. Rago. 2007. Survey transition and calibration of bottom trawl surveys along the Northeastern Conti-
} 
and initiated a calibration study in which the catchability of the old vessel was compared with the new vessel (Miller et al. ${ }^{6}$ ).

\section{Data}

CPUE from the NEFSC bottom trawl survey was used as an index of relative abundance of spiny dogfish in the NES LME and was defined as the number of spiny dogfish caught per tow. To enable investigation of fishery behavior (i.e., effort and catch), CPUE was used to index local fish density and was defined as the number of spiny dogfish caught per hour fished. Spatial overlap analyses between spiny dogfish distribution and commercial fisheries were based solely on positive catches (i.e., CPUE >0) and did not depend upon magnitude. No attempts were made to standardize CPUE between gear types or compare magnitudes directly in any spatial analyses. Differences between effort allocation, gear configuration, and catchability invalidated direct comparison of any trends in relative abundance between the survey and fisheries. Spatial locations were provided by latitudes and longitudes reported within both data sets.

Sampling during NEFSC bottom trawl surveys typically occurred over an 8-week period and proceeded from Cape Hatteras, North Carolina, north to the GM (Rago, 2005). These surveys generally lasted from September through November during autumn and from March through May during spring. Point data from the NEFOP showed that major fisheries, including the SGN and OT fisheries, covered both inshore and offshore regions of the NES LME between 1989 and 2009. The footprint of the SGN fishery and its coverage by observers expanded in that period. To enable temporal comparisons of spiny dogfish occurrence in the survey and in each fishery, the only fishery-dependent data that were used in analyses were collected during these time periods. Spatially, spiny dogfish distribution was comparable with fishery effort and catch because the overall footprint identified from the NEFOP covered much of the NES LME.

\section{Spatial distribution}

Spatial autocorrelation To assess the spatial pattern of spiny dogfish within each commercial fishery and the NEFSC bottom trawl survey, the spatial dependency among observations of spiny dogfish CPUE in geographic space (i.e., spatial correlation) was assessed through the use of Moran's I statistic (Moran, 1948; Goodchild, 1986). This statistic, calculated with the fol-

nental Shelf of the United States. ICES Committee Meeting (C.M.) document 2007/Q:20, 25 p.

${ }^{6}$ Miller, T. J., C. Das, P. J. Politis, A. S. Miller, S. M. Lucey, C. M. Legault, R. W. Brown, and P. J. Rago. 2010. Estimation of Albatross IV to Henry B. Bigelow calibration factors. Northeast Fish. Sci. Cent. Ref. Doc. 10-05, 233 p. [Available at http://www.nefsc.noaa.gov/publications/crd/crd1005/ crd1005.pdf.] lowing equation, provided the degree of clustering for points within a given distance $(d)$ :

$$
I_{\mathrm{d}}=\frac{n \sum_{\mathrm{ij}} w_{\mathrm{ij}}\left(x_{\mathrm{i}}-\bar{x}\right)\left(x_{\mathrm{j}}-\bar{x}\right)}{\left(\sum w_{\mathrm{ij}}\right) \sum_{\mathrm{i}=1}^{n}\left(x_{\mathrm{i}}-\bar{x}\right)^{2}},
$$

where $n=$ the number of observations, $x_{\mathrm{i}}$ and $x_{\mathrm{j}}$ are the attribute values (CPUE $\geq 0$ ) at points $i$ and $j$

$\bar{x}=$ the mean CPUE;

$w_{\mathrm{ij}}=$ the weighting function $\left(w_{\mathrm{ij}}=1\right.$ if points are within $d$, otherwise $w_{\mathrm{ij}}=0$ ) (Nielsen et al., 2007); and

$\Sigma_{\mathrm{ij}}=$ the sum over $i$ and $j$ with $i \neq j$.

Moran's $I$ tested the null hypothesis of a random spatial pattern in spiny dogfish CPUE (i.e., Moran's $I=0$ ) with values ranging from -1 (dispersed) to +1 (clustered). Moran's I was calculated in R software, vers. 2.14.0 ( $\mathrm{R}$ Development Core Team, 2011) with the spdep package and a spatial weights matrix based on the 5-nearest neighbors (Bivand et al., 2012).

Center of abundance Annual centers of spiny dogfish abundance (Marino et al., 2009) were estimated to identify and compare interannual locations of spiny dogfish catch for each fishery and the bottom trawl survey. This metric was calculated with the following equation:

$$
X_{\mathrm{j}}=\frac{\sum_{i=1}^{n} b_{\mathrm{i}} X_{\mathrm{ij}}}{\sum b_{\mathrm{i}}}
$$

where $X_{\mathrm{j}}=$ the parameter of interest (latitude, longitude) at station $i$ in year $j$; and

$b_{\mathrm{i}}=$ the $\log _{e}$-transformed abundance $\left(\log _{e}[\mathrm{CPUE}\right.$ $\geq 0]+0.05$ ) (Nye et al., 2009).

Annual centers of spiny dogfish abundance were mapped in ArcGIS ${ }^{7}$, vers. 10.1 (ESRI Corp., Redlands, CA). Annual centers of spiny dogfish abundance within each fishery do not reflect true shifts in distribution but instead reflect locations of catches (whether targeted or occurring as bycatch) on fishing grounds. In contrast, centers from the bottom trawl survey are unbiased representations of spiny dogfish distribution and, therefore, estimate true changes in the population distribution in the survey domain.

Annual centers of spiny dogfish abundance documented during the bottom trawl survey and each fishery were compared to determine whether the spatial locations of abundance differed for each season. Despite transformation efforts, non-normality and highly correlated dependent variables prevented the use of parametric techniques (Quinn and Keough, 2002). Instead, a one-way permutational multivariate analysis of variance (Anderson, 2001), for analysis of variance with a balanced design based on Bray-Curtis distances, was used to test for differences in location through the

\footnotetext{
${ }^{7}$ Mention of trade names or commercial companies is for identification purposes only and does not imply endorsement by the National Marine Fisheries Service, NOAA.
} 
use of the program PERMANOVA, vers. 1.6 (formerly called NPMANOVA; Anderson, 2005). This method tested for the multivariate null hypothesis of no relationship between modes of fishing (i.e., fisheries versus survey) (Anderson, 2001). A multivariate test statistic analogous to Fisher's $F$-ratio was calculated directly from a dissimilarity matrix with the $P$-value obtained by both permutation and Monte Carlo randomization (Anderson, 2001).

For comparisons between the bottom trawl survey and each fishery, the mode of fishing was treated as a fixed factor, the dependent variables latitude and longitude defined centers of spiny dogfish abundance, and annual values served as observations. Significance was determined by 9999 permutations of the raw data and an a priori significance level of $\alpha=0.05$. If the result was statistically significant, a posteriori pairwise comparisons were conducted with 9999 permutations to determine which modes of fishing differed significantly (Anderson, 2001). All a posteriori significance levels $(\alpha=0.05)$ were adjusted through the use of the Bonferroni correction method $\left(\alpha_{a d j}=0.0167\right)$ to reduce the potential for type-I errors during multiple comparisons (Crawley, 2007).

\section{Spatial analyses}

Grid determination with semivariograms A comparable grid scheme of spatially identical grid cells enabled direct comparison and geostatistical modeling to quantify the spatiotemporal overlap between spiny dogfish distribution and commercial fisheries. Empirical semivariograms $(\gamma[h])$ estimated the range $(a)$ or the asymptotic distance beyond which samples were spatially independent (Matheron, 1971). For each year, survey and fishery CPUE of spiny dogfish were $\log _{e}$ transformed $\left(\log _{e}[\mathrm{CPUE} \geq 0]+0.05\right)$ to meet the normality requirement for semivariogram modeling and to account for zero values. Semivariograms were fitted both annually and overall (i.e., all years combined). After multiple theoretical models (nugget, spherical, Gaussian, and exponential) were tested, the optimal model given the data was selected on the basis of the lowest Akaike's information criterion (Webster and McBratney, 1989) and of model weights (Wagenmakers and Farrell, 2004). All models were run in $\mathrm{R}$ software with the gstat package (Pebesma, 2004). Annual range estimates averaged across years were compared to range estimates obtained from all the data. Further details regarding semivariogram modeling are provided in the Appendix.

Spatial overlap Seasonal spatial overlap was quantified on an annual basis to examine how spiny dogfish distribution was related to both commercial fishery effort and catch throughout the NEFOP time series (1989-2009). First, station data for the NEFSC bottom trawl survey and each fishery were converted into rasters with the raster package (Hijmans et al., 2012) in $\mathrm{R}$ to summarize data points and interpolate catch (survey and fishery) in grid cells that were not directly sampled and, therefore, to enable estimation of spatial overlap outside the spatial domain. Grid cells for which CPUE $>0$ (i.e., positive catch of spiny dogfish by fishery) were identified and used in spatial overlap analyses concerning fishery catch. The magnitude of CPUE was not considered in any spatial analyses.

We assessed the amount of direct spatial overlap (Brodeur et al., 2008) between spiny dogfish distribution and 2 aspects of each commercial fishery: 1) effort, indicative of where a fishery fished (fleet presence), and 2) catch, indicative of spiny dogfish presence on the fishing grounds. The percentage of spatial overlap of spiny dogfish distribution with commercial fisher effort $\left(S O_{\mathrm{E}}\right)$ was calculated with the following equation:

$$
S O_{\mathrm{E}}(\%)=\frac{N_{\mathrm{SC}, \mathrm{FE}}}{N_{\mathrm{FE}}} \times 100,
$$

where $N_{\mathrm{SC}, \mathrm{FE}}=$ the number of grid cells that contained both survey catch of spiny dogfish and commercial fishery effort; and

$N_{\mathrm{FE}}=$ the number of surveyed grid cells representing areas that were fished.

This metric described how each commercial fishery was operating in relation to distribution of spiny dogfish and served as a proxy of spiny dogfish availability to the OT and SGN fisheries. Low overlap indicated that fishing crews were infrequently encountering spiny dogfish (whether directly or as bycatch), indicating reduced availability to the fishery. The footprint of the $S O_{\mathrm{E}}$ metric was equivalent to the fishing grounds because only fished areas contributed toward the denominator (sites that were surveyed but not fished had no bearing on $S O_{\mathrm{E}}$ ).

The percentage of spatial overlap of spiny dogfish distribution with commercial fishery catch $\left(\mathrm{SO}_{\mathrm{C}}\right)$ was calculated with an equation similar to Equation 3:

$$
S O_{\mathrm{C}}(\%)=\frac{N_{\mathrm{SC}, \mathrm{FC}}}{N_{\mathrm{FC}}} \times 100,
$$

where $N_{\mathrm{SC}, \mathrm{FC}}=$ the number of grid cells that contained both survey and fishery catch of spiny dogfish; and

$N_{\mathrm{FC}}=$ the number of surveyed grid cells where commercial fishing crews caught spiny dogfish.

This metric represented the similarity between the commercial fishery and the bottom trawl survey in encountering spiny dogfish. Here, low overlap indicated a spatial mismatch between the area where the fishery and the survey caught spiny dogfish. The footprint of the $S O_{\mathrm{C}}$ was based on fishing grounds where spiny dogfish were encountered. As explained previously for $S O_{\mathrm{E}}$, sites that were surveyed but not fished had no bearing on $\mathrm{SO}_{\mathrm{C}}$.

In addition to estimation of direct spatial overlap with station data, estimation of spatial overlap was done with interpolated survey and fishery catch. Semivariograms were used in conjunction with ordinary kriging (Oliver and Webster, 1990; Reese and 
Brodeur, 2006; Brodeur et al., 2008) to estimate survey and fishery catch outside the sampled domain. To assess ordinary kriging model performance, model diagnostics (including root mean square error of prediction [RMSE] and variance estimates from 100-fold cross-validation) were investigated (Cressie, 1993). All analyses were carried out in $\mathrm{R}$ with the gstat package (Pebesma, 2004). After interpolation of survey and fishery catch throughout the NES LME, geostatistical spatial overlap of predicted spiny dogfish distribution with predicted fishery catch $\left(S O_{\mathrm{I}}\right)$ was calculated with the following equation:

$$
S O_{\mathrm{I}}(\%)=\frac{N_{\mathrm{SI}, \mathrm{FI}}}{N_{\mathrm{FI}}} \times 100,
$$

where $N_{\text {SI,FI }}=$ the number of grid cells with predicted survey and fishery catch of spiny dogfish; and

$N_{\mathrm{FI}}=$ the number of grid cells with predicted fishery catch.

As with $S O_{\mathrm{C}}$, this metric provides insight regarding the area where both the commercial fishery and bottom trawl survey were predicted to catch spiny dogfish but does so over a larger spatial scale. Here, low overlap indicated that the fishery caught spiny dogfish that were not accounted for by the bottom trawl survey. The footprint of the $S O_{\text {I }}$ encompassed predicted fishing grounds inhabited by spiny dogfish. As explained previously for $S O_{\mathrm{C}}$ and $S O_{\mathrm{E}}$, sites that were surveyed but not fished had no bearing on $S O_{\mathrm{I}}$.

\section{Availability to fishery}

The percentage of spiny dogfish stock available to each commercial fishery was used to infer changes in catchability of the population, in the sense that increased availability could lead to increased catchability. Annual estimates were obtained with the following equation:

$$
\text { Availability }(\%)=\frac{C_{\mathrm{F}}}{C_{\mathrm{T}}} \times 100,
$$

where $C F=$ the total survey catch of spiny dogfish in grid cells where commercial fishing occurred; and

$C \mathrm{~T}=$ the total survey catch of spiny dogfish.

Availability was reported both overall (i.e., for all spiny dogfish) and separately for each life-history stage because of sex-specific trends in habitat preference and distribution (Sagarese et al., 2014b). The life-history stages that were examined included aggregated male and female neonates ( $\leq 26 \mathrm{~cm}$ in total length [TL]), immature males ( $>26 \mathrm{~cm}$ TL and $<60 \mathrm{~cm}$ TL), immature females ( $>26 \mathrm{~cm}$ TL and $<80 \mathrm{~cm}$ TL), mature males $(\geq 60$ $\mathrm{cm}$ TL), and mature females ( $\geq 80 \mathrm{~cm}$ TL). We assumed that the survey catch was representative of trends for the entire spiny dogfish stock and also for individual life-history stages throughout the NES LME. A high percentage indicated that a large portion of the spiny dogfish stock was present in areas represented by the grid cells where commercial fisheries were operating.

For each fishery, the relationship between availability and $\log _{\mathrm{e}}$-transformed abundance of spiny dogfish was examined with annual values considered observations. This analysis focused on mature females because this stage is preferentially landed for maximal profit in the highly sex-selective fishery for spiny dogfish (Rago et al., 1998) and also because of their close proximity to shore (Sagarese et al., 2014b). Between 1982 and 1995, 95\% of sampled landings were mature females $\left(\mathrm{NEFSC}^{3}\right)$.

\section{Correlation between fisheries and survey catch data}

We investigated annual correlations between commercial fisheries (effort and catch) and survey catch of spiny dogfish (Park and Obrycki, 2004). Map-correlation coefficients were calculated on the basis of sample-to-sample correlations in which grid cells were treated as samples. Pearson's coefficient of correlation $(r)$ measured the "strength" of the relationship, and Spearman's rank correlation coefficient $\left(r_{\mathrm{sp}}\right)$ measured the similarity between ranks of observed and predicted values (Quinn and Keough, 2002).

\section{Results}

\section{Comparison of data from different gears}

Preliminary analysis of observer data from the NEFOP revealed that the majority of spiny dogfish were captured by the SGN (autumn: 57\%; spring: 47\%) and OT fisheries (autumn: 29\%; spring: 45\%). Therefore, all analyses focused on these 2 fisheries. Data for these fisheries covered the longest and most continuous time series (1989-2010). The SGN fishery expended more effort (in hours fished) and kept a larger percentage of spiny dogfish catch (autumn: 61\%; spring: $82 \%$ ) than the OT fishery (autumn: 8\%; spring: 6\%). Annual discards $(\%)$ of spiny dogfish for the OT fishery generally exceeded 85\% during both seasons, although a few exceptions were noted in the mid- to late 1990s (range: from $20 \%$ [1996] to $68 \%$ [1999]). In contrast, annual discards of spiny dogfish for the SGN fishery were highly variable during both seasons (spring: 1-100\%; autumn: 1-90\%) but exhibited consistently low values during the mid- to late 2000s. Interannual differences existed in the percentage of discarded catch, likely because of the complex history of dogfish harvest-which began in 1990, was shut down in 1999, and was primarily bycatch in the 2000 s.

Estimates of mean percent observer coverage (the number of trips observed compared with the number of commercial trips reported) were as follows: northeast SGN (1990-2008: 5.1\% [standard deviation (SD) 1.7]), mid-Atlantic SGN (1995-2008: 2.9\% [SD 1.3]), northeast bottom trawl (including beam, bottom fish [otter], bottom shrimp, and bottom scallop trawls) (1994-2008: 3.2\% [SD 3.6]), and mid-Atlantic bottom 


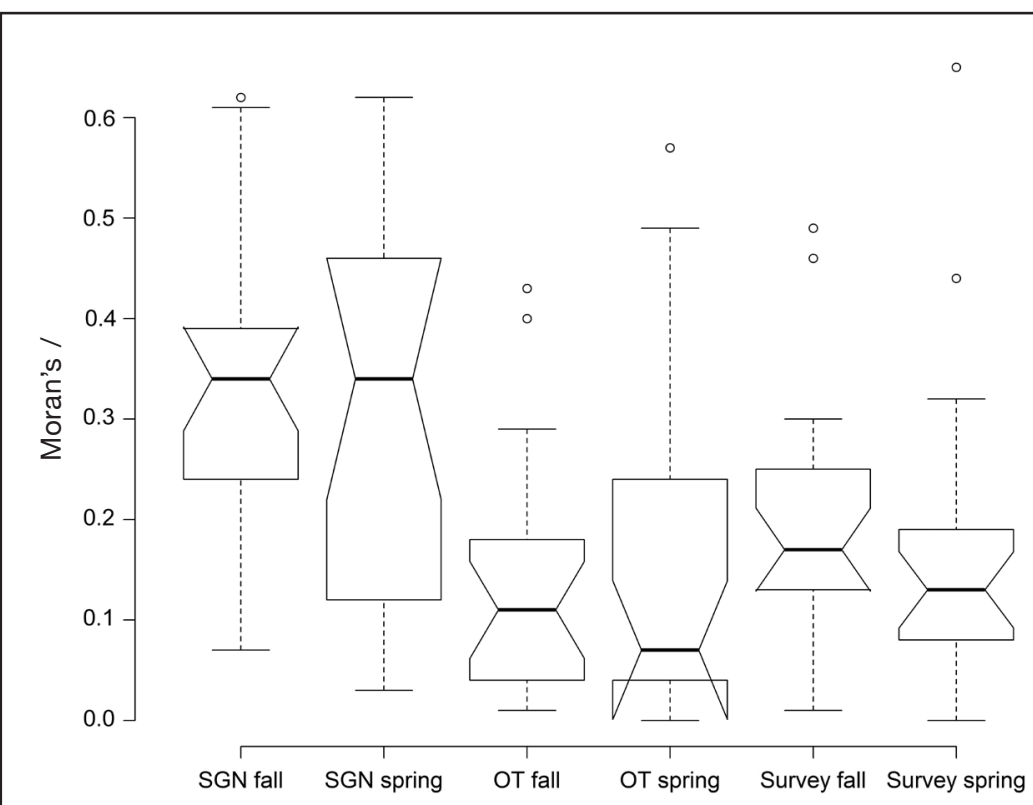

Figure 1

Seasonal clustering of spiny dogfish (Squalus acanthias) catch per unit of effort (CPUE) in the northeast U.S. shelf large marine ecosystem between 1989 and 2009 during autumn and spring for the sink gillnet (SGN) fishery, otter trawl (OT) fishery, and Northeast Fisheries Science Center bottom trawl survey (Survey). Moran's $I$ statistic ranges from +1.0 (clustered) to -1.0 (dispersed) with values of 0.0 indicative of a random spatial association. The thick horizontal line indicates the median, the notched box represents the interquartile range and the $25^{\text {th }}$ (bottom) and $75^{\text {th }}$ (top) percentiles, and the whiskers show either the maximum value or 1.5 times the interquartile range. Nonoverlapping notches provide a rough impression of the significance of the differences between medians.

LME with the exception of GB, and the OT fishery operated both on the NES LME and along its edge.

\section{Spatial distribution}

Seasonal spatial patterns of spiny dogfish CPUE were significantly more clustered in the SGN fishery (Moran's $I$ median: 0.31 ) than in the OT fishery (Moran's $I$ median: $0.07-0.11$ ) and the bottom trawl survey (Moran's I median: 0.13-0.17 (Fig. 1; significance determined by lack of overlap in notches). Although seasonal medians in Moran's $I$ were higher during autumn than during spring for the OT fishery and the survey, these differences were not statistically significant. CPUE estimates from both the OT fishery and the bottom trawl survey were characterized by low Moran's $I(<0.2)$ throughout the time series, indicating a fairly random spatial association of spiny dogfish CPUE (Fig. 1). Overall, the paucity of negative Moran's $I$ values indicates that spiny dogfish CPUE was never dispersed.

\section{Centers of abundance}

Annual centers of spiny dogfish catches differed significantly during both seasons for each fishery and for the bottom trawl survey $(P<0.05$; Table

trawl (1996-2008: 1.4\% [SD 1.2]) (Waring et al., 2011). Mean rates of spiny dogfish bycatch for the northeast (94.8\% [SD 5.2]) and mid-Atlantic (89.7\% [SD 14.0]) OT fisheries were similar but differed by a factor of 2 between the northeast $(42.0 \%$ [SD 29.1]) and midAtlantic (22.2\% [SD 24.0]) SGN fisheries. Fishery behavior was assumed similar between the northeast and mid-Atlantic regions for each commercial fishery and, therefore, regional trends were combined for all analyses.

\section{Distribution of seasonal catch}

Both commercial fisheries operated year-round in all 4 regions that are covered by the NEFSC bottom trawl survey. Although spiny dogfish were encountered in each region during all months, they were less commonly encountered in the Mid-Atlantic Bight during summer months. During cooler months (November through April), high catches of spiny dogfish occurred off Cape Hatteras, North Carolina, in both fisheries. In contrast, during warmer months (May through October), spiny dogfish were more common throughout the GM and on GB. The SGN fishery operated throughout the NES
$1)$, matching expected trends in seasonal availability. In addition, the locations of these centers differed significantly among modes of fishing $\left(P_{\text {adj }}<0.0167\right.$; Table 1 ), with the exceptions of the bottom trawl survey versus the SGN fishery during autumn and the survey versus the OT fishery during spring. During autumn, both the survey and SGN fishery frequently encountered spiny dogfish in the southwestern GM (Fig. 2A). Centers of abundance from the survey were located farthest offshore in the central GM between the early to mid-1990s (Fig. 2A). During spring, spiny dogfish were encountered along the edge of the continental shelf in SNE during both survey and OT fishery trips (Fig. 2B). Centers of spiny dogfish abundance determined from SGN fishery data revealed a northward shift during much of the 2000s (Fig. 2B).

\section{Spatial analyses}

Grid size A grid cell size of $0.25^{\circ}$ latitude $\times 0.25^{\circ}$ longitude was selected and resulted in 468 grid cells, with grid areas ranging from $532 \mathrm{~km}^{2}$ to $644 \mathrm{~km}^{2}$ in the northernmost and southernmost grids, respectively. Although annual semivariogram trends were investi- 


\section{Table 1}

Permutational multivariate analysis of variance on Bray-Curtis distances for the center of spiny dogfish (Squalus acanthias) abundance based on 3 modes of fishing, sink gillnet (SGN), otter trawl (OT), and the Northeast Fisheries Science Center (NEFSC) bottom trawl survey (Surv), during autumn and spring between 1995 and 2009 in the northeast U.S. shelf large marine ecosystem. Overall significance $(*)$ is based on an a priori $\alpha=0.05$, and comparison significance is based on an adjusted $\alpha$ of 0.0167 ( $\alpha=0.05$ corrected for 3 comparisons between modes of fishing). Pairwise a posteriori comparisons were executed with $t$, a multivariate version of the $t$-statistic based on distances. Note that the period from 1989 through 1994 was excluded from analysis because of a lack of coverage of the Mid-Atlantic Bight by the NEFSC Northeast Fishery Observer Program for the sink gillnet fishery. $d f=$ degrees of freedom; $\mathrm{SS}=$ sums of squares; MS=mean square; $F=$ pseudo- $F$ ratio test statistic; $P$ (perm)=permutated $P$-value; MC=Monte Carlo asymptotic $P$-value.

\begin{tabular}{|c|c|c|c|c|c|c|}
\hline Source & $\mathrm{df}$ & SS & MS & $F$ & $P($ perm $)$ & $P(\mathrm{MC})$ \\
\hline \multicolumn{7}{|l|}{ Autumn } \\
\hline Modes of fishing & 2 & 81.48 & 40.74 & 10.04 & $0.0002^{*}$ & $0.0002 *$ \\
\hline Residual & 42 & 170.50 & 4.06 & & & \\
\hline Total & 44 & 251.97 & & & & \\
\hline \multicolumn{7}{|l|}{ Spring } \\
\hline Modes of fishing & 2 & 260.88 & 130.44 & 18.16 & $0.0001^{*}$ & $0.0001 *$ \\
\hline Residual & 42 & 301.59 & 7.18 & & & \\
\hline Total & 44 & 562.47 & & & & \\
\hline Comparison & & & & & $P($ perm $)$ & $P(\mathrm{MC})$ \\
\hline \multicolumn{7}{|l|}{ Autumn } \\
\hline SGN vs OT & \multicolumn{4}{|c|}{3.366} & $0.0005^{*}$ & $0.0019^{*}$ \\
\hline SGN vs Surv & \multicolumn{4}{|c|}{2.313} & 0.0148 & 0.0202 \\
\hline OT vs Surv & \multicolumn{4}{|c|}{4.918} & $0.0001 *$ & $0.0001^{*}$ \\
\hline \multicolumn{7}{|l|}{ Spring } \\
\hline SGN vs OT & \multicolumn{4}{|c|}{7.692} & $0.0001^{*}$ & $0.0001^{*}$ \\
\hline SGN vs Surv & \multicolumn{4}{|c|}{3.853} & $0.0006^{*}$ & $0.0004^{*}$ \\
\hline OT vs Surv & \multicolumn{4}{|c|}{1.421} & 0.1659 & 0.1682 \\
\hline
\end{tabular}

gated across gears and seasons, model structure and range estimates were similar to those obtained across all years. Ranges obtained from optimal semivariogram models varied from $0.10 \mathrm{~km}$ to $20.19 \mathrm{~km}$ and rarely exceeded $2 \mathrm{~km}$ (Table 2) when examined annually. The large range identified for the OT fishery during spring was driven by trends in 1995 and 2003. Details on semivariogram fits and model selection are provided in Appendix Figure 1 and Appendix Table 1, respectively, in the Appendix.

Spatial overlap of spiny dogfish distribution with fishery effort For the SGN fishery, $S O_{\mathrm{E}}$ during autumn generally exceeded estimates during spring, indicating that a greater portion of the spiny dogfish stock was available to that fishery during autumn (Fig. 3A). During spring, $S O_{\mathrm{E}}$ gradually increased throughout the $1990 \mathrm{~s}$ and remained relatively high for the remainder of the time series (Fig. 3A). For the OT fishery before 1997, $S O_{\mathrm{E}}$ during spring consistently exceeded $S O_{\mathrm{E}}$ during autumn (Fig. 3B). $S O_{\mathrm{E}}$ for the OT fishery showed a trend of slightly increasing values over time during autumn but no noticeable pattern during spring (Fig. 3B).
Spatial overlap of spiny dogfish distribution with fishery catch For the SGN, lower $S O_{\mathrm{C}}$ during spring, compared with values during autumn, indicated less overlap between spiny dogfish distribution and the areas where the SGN encountered them (Fig. 4, A and B). During spring, $S O_{\mathrm{C}}$ values ranged from $0 \%$ in 1990 and 1991 to peak estimates in the late 2000s (overall mean 47\% [SD 24]) (Fig. 4B). Predicted spatial distributions of spiny dogfish estimated with interpolation methods were accompanied by reasonable 100 -fold cross-validation errors for the SGN fishery and the bottom trawl survey, whereas RMSE estimates from mean predictions were large for the survey (Table 3 ). $S O_{\text {I }}$ yielded trends similar to those observed for $S O_{\mathrm{C}}$ and often exceeded $S O_{\mathrm{C}}$ estimates during both seasons (Fig. 4, A and B). During spring, $S O_{\mathrm{I}}$ was relatively high with the exception of values in the mid-2000s (overall mean 48\% [SD 34]) (Fig. 4B). SO I estimated for the period 2003-2006 was 0 because of small predicted catches $(<0.5)$ that were converted into either presence $(\geq 0.5)$ or absence $(<0.5)$ for analyses. Saturated values (i.e., 100\%) of $S O_{\text {I }}$ were often artifacts of very low sample sizes ( $<10$ grid cells) used during interpolation. 


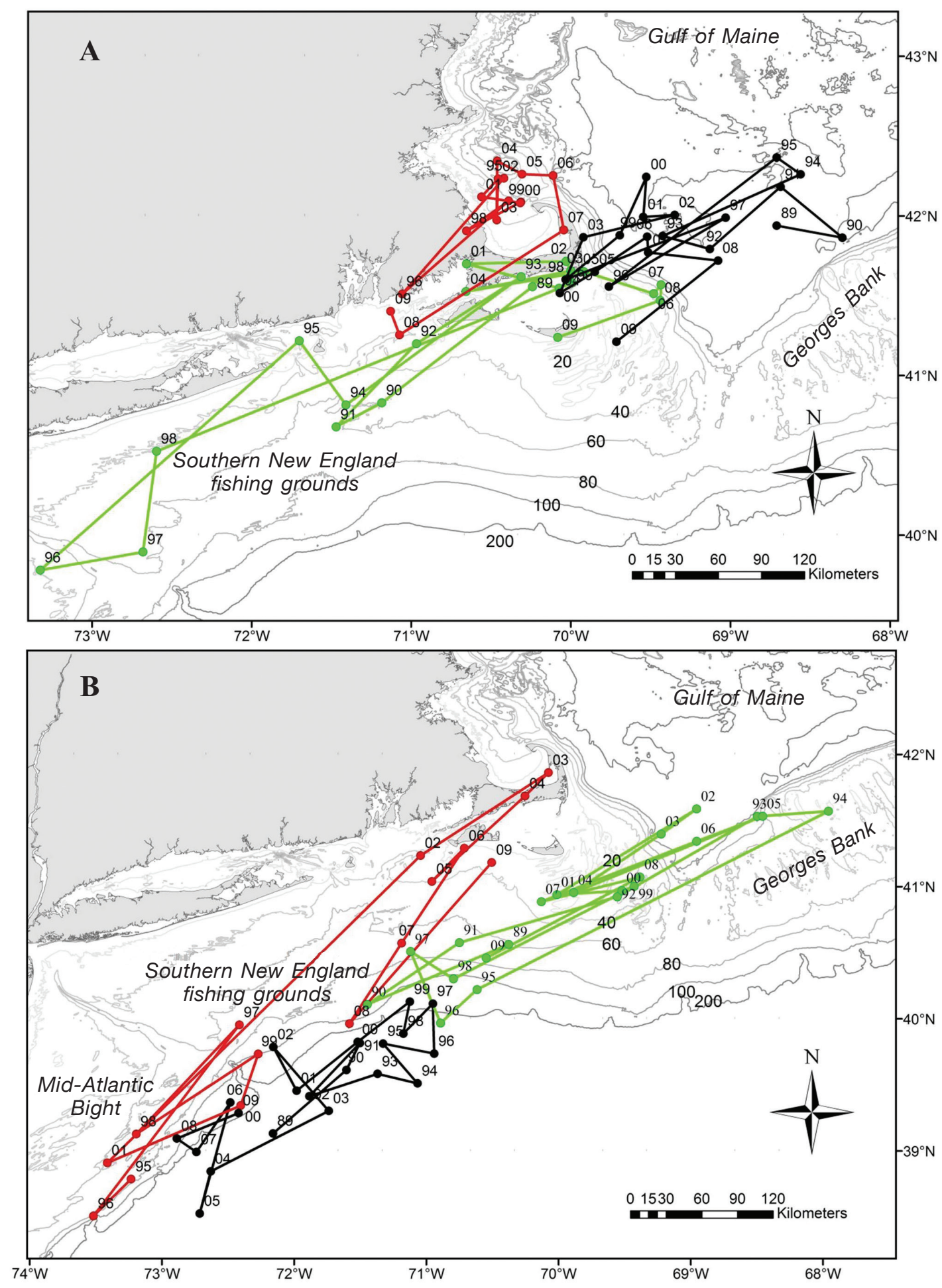

Figure 2

Annual centers of spiny dogfish (Squalus acanthias) abundance in the northeast U.S. shelf large marine ecosystem between 1989 and 2009 during (A) autumn and (B) spring as observed in the sink gillnet fishery (red line), otter trawl fishery (green line), and Northeast Fisheries Science Center (NEFSC) bottom trawl survey (black line). Shaded gray area indicates land mass. Gray lines represent depth contours (200-, 100-, 80-, 60-, 40-, and 20-m isobaths). Note that values for the sink gillnet fishery start in 1995 because of the commencement of the NEFSC Northeast Fishery Observer Program in the mid-Atlantic. Numbers on each colored line refer to years, where $89=1989,90=1990,00=2000$, and so on. 


\section{Table 2}

Best-fit semivariogram models and parameters for the spatial distribution of spiny dogfish (Squalus acanthias) catch per unit of effort (CPUE) for the sink gillnet (SGN) and otter trawl (OT) fisheries and in the Northeast Fisheries Science Center bottom trawl survey (Survey) between 1989 and 2009 during autumn and spring in the northeast U.S. shelf large marine ecosystem. Semivariogram parameters included the sill $\left(C_{\mathrm{s}}\right)$, the nugget $\left(C_{0}\right)$, and the range $(a)$. Anisotropy parameters included the ratio of the minor to major lengths (Ratio) and the angle for the principal direction of continuity (Angle). Models include exponential (Exp), Gaussian (Gau), and spherical (Sph).

\begin{tabular}{lcrrrrr}
\hline Gear & Model & \multicolumn{1}{c}{$C_{\mathrm{S}}$} & $C_{0}$ & $a(\mathrm{~km})$ & Ratio & Angle $\left(^{\circ}\right)$ \\
\hline Autumn & & & & & & \\
SGN & Exp & 6.74 & 0.00 & 0.10 & 0.93 & 54 \\
OT & Gau & 4.94 & 6.16 & 1.79 & 0.93 & 141 \\
Survey & Exp & 3.45 & 4.94 & 1.57 & 0.91 & 130 \\
Spring & & & & & & \\
SGN & Gau & 2.30 & 1.90 & 1.31 & 0.73 & 30 \\
OT & Exp & 12.02 & 4.80 & 20.19 & 0.98 & 39 \\
Survey & Sph & 4.37 & 4.76 & 1.38 & 0.76 & 37 \\
& & & & & & \\
\hline
\end{tabular}

For the OT fishery, the magnitude of $S O_{\mathrm{C}}$ was relatively similar between seasons but differed in trend (Fig. 4, C and D). During autumn, a period of relatively low $\mathrm{SO}_{\mathrm{C}}(42 \%$ [SD 11.5]) was observed in 1990-1997 and higher $S O_{\mathrm{C}}$ was seen in 1998 and thereafter $(68 \%$ [SD 12.2] (Fig. 4C). In contrast, no pattern was evident during spring (Fig. 4D). Predicted spatial distributions of spiny dogfish estimated with interpolation methods for the OT fishery revealed reasonable mean prediction and 100-fold cross-validation errors (Table 3). For this fishery, trends between $S O_{\mathrm{C}}$ and $S O_{\mathrm{I}}$ were similar during autumn but more variable during spring. Dur-

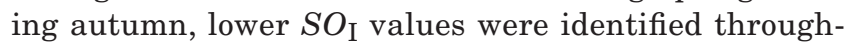
out the mid-1990s (Fig. 4C). During spring, $S O_{\mathrm{I}}$ values were consistently larger than $S O_{\mathrm{C}}$ estimates; however, a marked reduction was observed during the early to mid-2000s (Fig. 4D).

\section{Availability to fishery}

Aggregated spiny dogfish The percentage of the spiny dogfish stock available to both fisheries was generally higher during autumn than during spring (Fig. $5 \mathrm{~A}$ ), indicating that a greater portion of the population was available to each commercial fishery during this season. In general, availability to the SGN fishery remained below $30 \%$ with the exception of availability in the mid- to late 2000s (Fig. 5A). Although a similar pattern was observed for the OT fishery during spring, availability to this fishery during autumn increased abruptly in 2001 and remained high (Fig. 5A).

Stage-dependent availability The availability of each life-history stage of spiny dogfish was highly vari- able for fisheries and seasons (Fig. 5). Sporadic survey catches of neonates, particularly during autumn, resulted in erratic (and potentially unreliable) trends for both seasons and fisheries (Fig. 5B). Patterns in availability of immature males were also relatively inconsistent throughout the time series, although analyses indicated recent increases for the OT fishery during both seasons (Fig. 5C). Availability of mature males, immature females, and mature females revealed similar trends, namely recent increases and higher availability during autumn than during spring for both fisheries (Fig. 5, D-F).

Abundance of mature female spiny dogfish from the bottom trawl survey was related significantly to availability of mature female spiny dogfish to the OT fishery during autumn (availability $=22.269 \log _{e}[$ CPUE $]+$ 10.954 , coefficient of multiple determination $\left[R^{2}\right]=0.48$, $P=0.0005$ ) and to the SGN fishery during spring (availability=-7.867 $\log _{e}[\mathrm{CPUE}]+24.217, R^{2}=0.24, P=0.0236$ ) (Fig. 6). As abundance increased during autumn, the percentage of mature females available to the OT fishery increased significantly (Fig. 6A). The relationship between survey abundance and availability to the SGN fishery revealed an opposite but significant trend during spring. As abundance of mature females increased, the percentage available to the SGN fishery decreased significantly (Fig. 6B).

\section{Correlation between fisheries and survey catch data}

Spiny dogfish distribution was not highly correlated with commercial fishery effort for either fishery $\left(r<0.23, r_{\mathrm{sp}}<0.43\right)$. Although most correlations between spiny dogfish distribution and fishery catch $\left(S O_{\mathrm{C}}, S O_{\mathrm{I}}\right)$ 


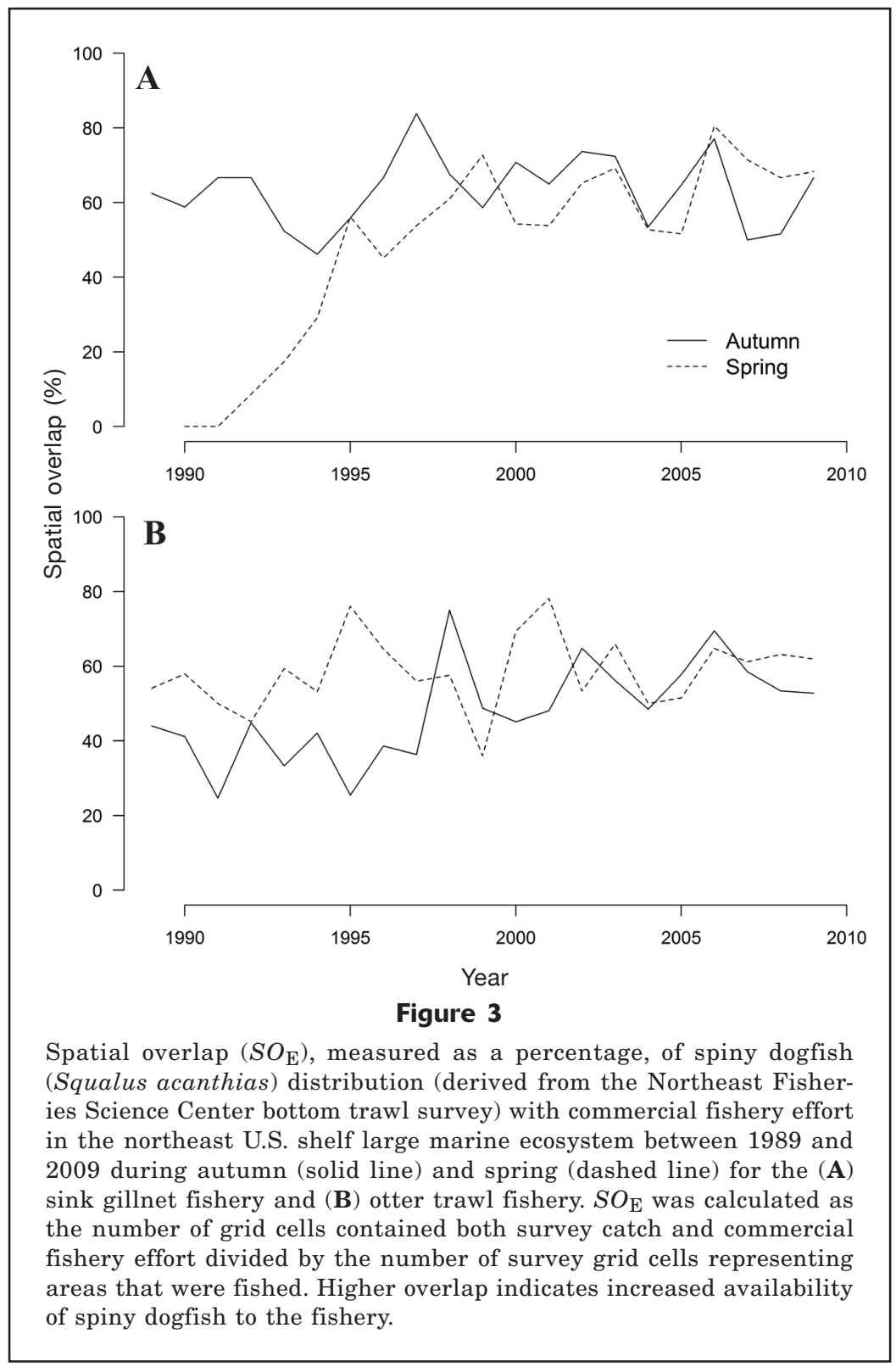

were also relatively weak, some exceptions were noted. Interpolated values resulted in moderate to high correlations $\left(r_{\mathrm{sp}}\right.$ : autumn: -0.02 to 0.75 ; spring: -0.54 to $0.33)$ for the SGN fishery during both seasons. The OT fishery also displayed moderate correlations $\left(r_{\mathrm{sp}}<0.66\right)$ during each season.

\section{Discussion}

Spatial overlap analyses indicate that changes in availability of spiny dogfish to commercial fisheries may have been manifested as apparent increases in local abundance on commercial fishing grounds. Increased co-occurrence of spiny dogfish with commercial fisheries was further indicated by availability analyses that assessed the annual percentage of the spiny dogfish stock that was located on SGN and OT fishing grounds between 1989 and 2009. A proxy for spawning stock biomass, abundance of mature female spiny dogfish was significantly related to availability for each commercial fishery, although the pattern was not consistent among fisheries. Spatial overlap analyses revealed recent increases for both the SGN and OT fisheries but not consistently across seasons. Analysis of fishery-dependent data revealed differences in fishery behavior between the SGN and OT fisheries: a high spiny dogfish bycatch in the OT fishery and high retained catch in the SGN fishery indicative of targeting. Seasonal examination of centers of spiny dogfish abundance revealed differences between inshore and offshore areas, with trends in data from the bottom 


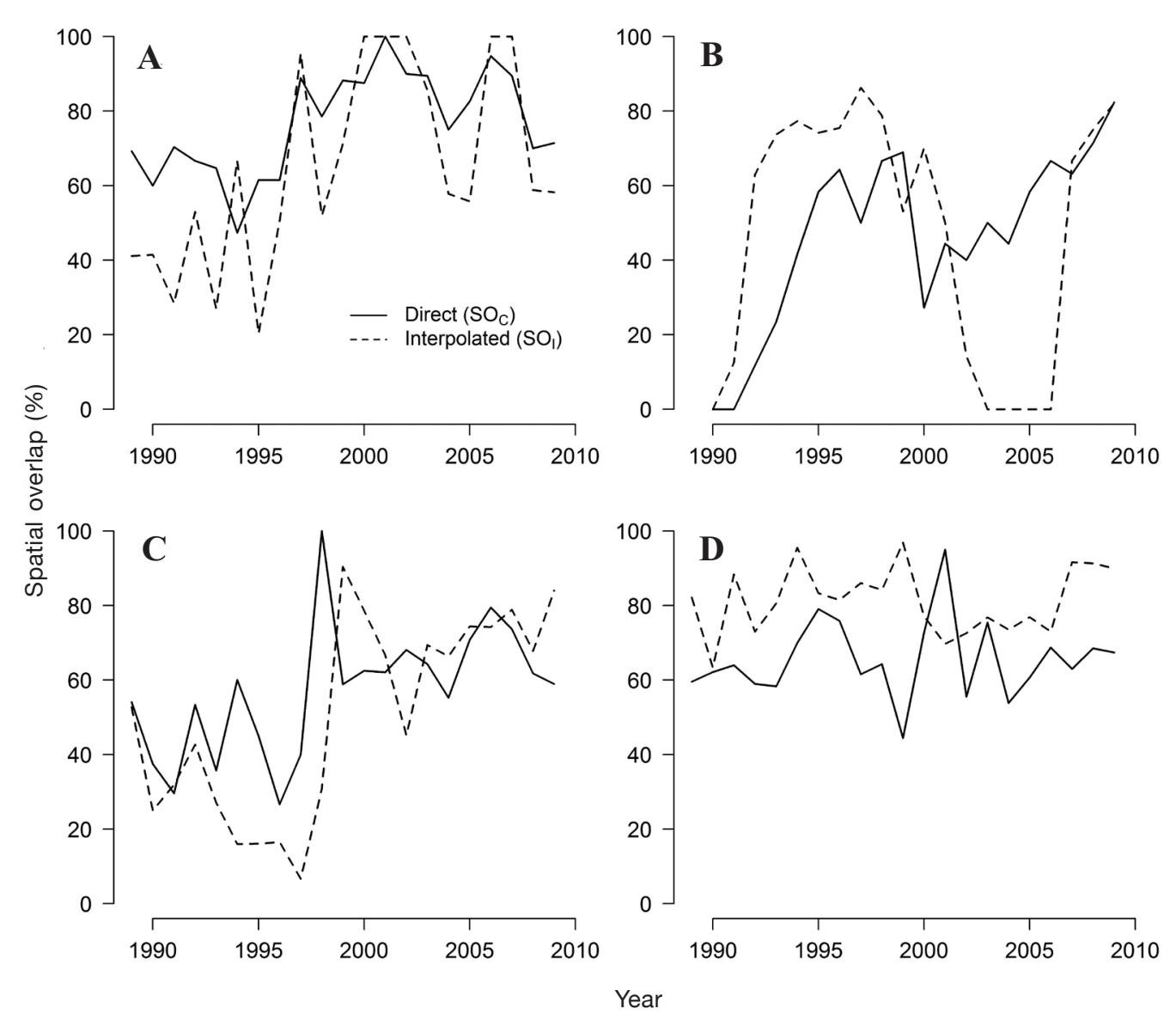

Figure 4

Spatial overlap $\left(S O_{\mathrm{C}}, S O_{\mathrm{I}}\right)$, measured as a percentage, of spiny dogfish (Squalus acanthias) distribution (derived from the Northeast Fisheries Science Center trawl survey data) with commercial fishery catch in the northeast U.S. shelf large marine ecosystem between 1989 and 2009 for the sink gillnet fishery in (A) autumn and (B) spring and the otter trawl fishery in (C) autumn and (D) spring. Solid lines indicate direct spatial overlap $\left(S O_{\mathrm{C}}\right)$, and dashed lines indicate spatial overlap revealed through the use of interpolated values $\left(S O_{\mathrm{I}}\right)$. Higher values indicate increased overlap between spiny dogfish distribution and fishery catches.

trawl survey validating seasonal movements of spiny dogfish (Sagarese et al., 2014b). Trends in fishery-dependent data displayed interannual differences in locations where spiny dogfish were encountered on commercial fishing grounds.

Availability can be understood as a localized effect between CPUE and density of spiny dogfish (Wilberg et al., 2009). Changes in availability to commercial fisheries can have long-lasting impacts on marine resources, especially on species, such as the spiny dogfish, which has a slow life history (Musick, 1999). During the $1990 \mathrm{~s}$, a southward shift in distribution of Atlantic cod increased the availability of this stock to fishing fleets and helped contribute to its collapse (Rose et al., 1994; Rose and Kulka, 1999). For spiny dogfish, the observed increase in $S O_{\mathrm{E}}$ throughout the time series for the SGN fishery during spring and for the OT fishery during autumn indicates a concomitant increase in the portion of the stock available to fisheries. Results from an availability analysis, in addition to quantified spatial overlap, support recent increases in availability of spiny dogfish and revealed changes in availability for individual life-history stages. Increased overlap may stem from technological advancements or social networking that can increase the efficiency of fishing crews in locating and capturing aggregations of either spiny dogfish directly or indirectly by targeting their prey (Hilborn and Walters, 1992).

The trend toward increased availability, particularly for mature females either as targeted catch or as bycatch, elicits the need for caution regarding the sustainability of the stock of spiny dogfish in the NES 
Table 3

Ordinary kriging model performance for prediction of catches of spiny dogfish (Squalus acanthias) from the sink gillnet (SGN) and otter trawl (OT) fisheries and the Northeast Fisheries Science Center bottom trawl survey (Survey) during autumn and spring between 1989 and 2009 in the northeast U.S. shelf large marine ecosystem. RMSE=root mean square error of prediction; $\mathrm{CV}=$ cross-validation; Var=variance. An en dash indicates no data were available. Additional metrics can be found in Sagarese. ${ }^{1}$

\begin{tabular}{|c|c|c|c|c|c|c|c|c|c|c|c|c|}
\hline \multirow[b]{3}{*}{ Year } & \multicolumn{6}{|c|}{ Mean prediction RMSE } & \multicolumn{6}{|c|}{ 100-fold CV Var } \\
\hline & \multicolumn{3}{|c|}{ Autumn } & \multicolumn{3}{|c|}{ Spring } & \multicolumn{3}{|c|}{ Autumn } & \multicolumn{3}{|c|}{ Spring } \\
\hline & SGN & OT & Survey & SGN & OT & Survey & SGN & OT & Survey & SGN & $\mathrm{OT}$ & Survey \\
\hline 1989 & 0.35 & 0.99 & 29.13 & - & 1.37 & 139.76 & 4.71 & 8.57 & 2.40 & - & 7.23 & 2.90 \\
\hline 1990 & 0.32 & 0.81 & 58.83 & 2.67 & 1.36 & 309.12 & 3.82 & 12.26 & 4.35 & 0.07 & 6.70 & 2.03 \\
\hline 1991 & 0.53 & 1.43 & 108.86 & 2.17 & 1.31 & 90.94 & 4.27 & 8.22 & 2.87 & 0.36 & 7.02 & 1.84 \\
\hline 1992 & 0.89 & 1.00 & 88.06 & 1.69 & 1.40 & 89.23 & 4.40 & 4.56 & 1.77 & 1.04 & 7.59 & 2.57 \\
\hline 1993 & 0.98 & 0.69 & 53.23 & 2.27 & 1.73 & 63.03 & 5.08 & 4.79 & 2.31 & 0.92 & 4.28 & 1.70 \\
\hline 1994 & 1.90 & 1.78 & 43.44 & 2.42 & 1.71 & 180.14 & 0.34 & 4.37 & 2.31 & 0.61 & 7.37 & 2.09 \\
\hline 1995 & 1.53 & 1.69 & 107.64 & 2.25 & 1.65 & 39.02 & 3.34 & 3.91 & 2.62 & 1.18 & 4.24 & 3.81 \\
\hline 1996 & 1.12 & 1.68 & 101.36 & 2.35 & 1.91 & 99.61 & 3.46 & 5.07 & 2.58 & 0.58 & 2.55 & 2.16 \\
\hline 1997 & 1.34 & 1.89 & 58.86 & 1.97 & 1.61 & 43.53 & 4.27 & 3.63 & 2.47 & 1.40 & 3.36 & 3.75 \\
\hline 1998 & 1.23 & 1.53 & 92.84 & 1.84 & 1.99 & 34.09 & 3.99 & 2.18 & 3.00 & 2.73 & 4.51 & 3.47 \\
\hline 1999 & 1.17 & 1.61 & 51.07 & 1.67 & 2.02 & 48.72 & 3.28 & 4.22 & 2.22 & 0.60 & 3.05 & 4.76 \\
\hline 2000 & 2.63 & 2.23 & 36.73 & 2.16 & 1.58 & 28.50 & 0.50 & 1.87 & 1.42 & 2.72 & 5.03 & 3.78 \\
\hline 2001 & 2.51 & 1.61 & 72.45 & 2.76 & 1.44 & 42.29 & 0.58 & 3.84 & 2.71 & 0.05 & 4.57 & 2.72 \\
\hline 2002 & 2.13 & 1.57 & 49.65 & 2.41 & 0.81 & 56.69 & 0.27 & 3.41 & 3.13 & 0.60 & 4.22 & 3.34 \\
\hline 2003 & 1.56 & 1.61 & 78.64 & 2.73 & 1.63 & 84.51 & 4.47 & 4.69 & 4.03 & 1.38 & 4.03 & 3.08 \\
\hline 2004 & 1.00 & 1.38 & 55.32 & 2.45 & 1.58 & 46.27 & 3.25 & 4.67 & 3.00 & 2.59 & 4.51 & 2.25 \\
\hline 2005 & 1.20 & 1.71 & 94.89 & 2.66 & 2.06 & 68.57 & 4.06 & 3.29 & 2.54 & 0.10 & 4.01 & 3.79 \\
\hline 2006 & 1.97 & 1.25 & 72.39 & 2.67 & 1.80 & 85.31 & 2.24 & 5.88 & 3.11 & 1.17 & 3.88 & 3.03 \\
\hline 2007 & 1.88 & 1.40 & 71.29 & 2.48 & 1.86 & 45.62 & 0.62 & 8.25 & 2.08 & 1.16 & 4.02 & 2.56 \\
\hline 2008 & 1.54 & 1.97 & 53.40 & 2.44 & 1.81 & 46.04 & 0.60 & 3.71 & 3.22 & 0.01 & 4.65 & 2.73 \\
\hline 2009 & 0.71 & 1.80 & 85.35 & 2.27 & 2.10 & 143.12 & 0.61 & 6.60 & 4.54 & 0.05 & 3.70 & 3.31 \\
\hline
\end{tabular}

${ }^{1}$ Sagarese, S. R. 2013. The population ecology of the spiny dogfish in the Northeast (US) shelf large marine ecosystem: implications for the status of the stock. Ph.D. diss., 501 p. Stony Brook Univ., Stony Brook, NY.

LME. Traditionally, mature female spiny dogfish were preferentially harvested for maximal profit and because they were close to shore (Shepherd et al., 2002; Sagarese et al., 2014b). Other factors, such as environmental conditions, also influence catchability observed in analyses of data from both surveys and fisheries, for example, by concentrating fish in preferred habitats (e.g., Smith and Page, 1996). Environmental conditions at the time of the NEFSC trawl survey influenced the probability of occurrence of life-history stages of spiny dogfish throughout the NES LME (Sagarese et al., 2014a). Changes in availability to monitoring surveys could affect abundance estimates used in stock assessment models (Methot and Wetzel, 2013).

Changes in the spatial distribution of spiny dogfish may also affect their availability to both commercial fisheries and monitoring surveys. Any change in spatial structure of the stock (Pennington and Godø, 1995), such as the documented shoreward shifts of spiny dogfish (NEFSC ${ }^{3}$ ), can increase availability and catchability if fish density increases on commercial fishing grounds. Increased availability to commercial fisheries can increase bycatch, which corresponds to higher levels of mortality from OTs (Mandelman and Farrington, 2007).

For spiny dogfish, a relationship was identified between abundance of mature females in the bottom trawl survey and their availability to each fishery. During autumn, availability to the OT fishery increased with mature female abundance. The plausibility of this result is supported by recent field studies that examined devices or repellents aimed at deterring spiny dogfish from multiple gears, including trawls, in the NES LME (Chosid et al., 2012; O'Connell et al., 2012). For the SGN fishery, an opposite trend of reduced availability was observed when there was a higher abundance of mature female spiny dogfish during spring. A potential explanation, based on MacCall (1990), is that as abundance increases mature females spread into offshore areas or seasonal areas less frequented by SGN fishing crews. It also is possible that the SGN fishery actively avoids large aggregations of mature female spiny dogfish because this nuisance species can overwhelm SGNs and either saturate some nets or destroy them (Tallack and Man- 


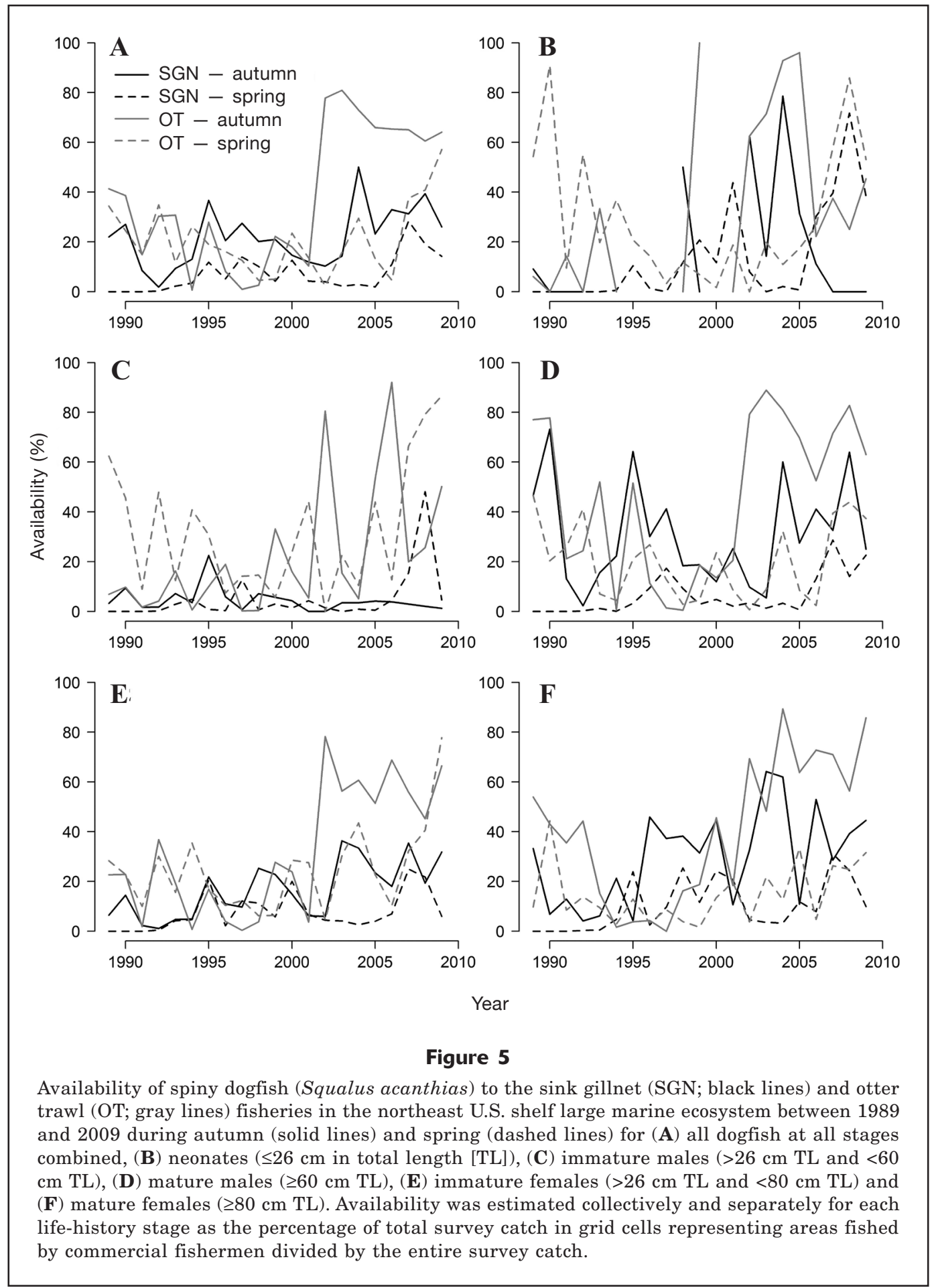

delman, 2009). Further, presence of nontargeted spiny dogfish can reduce the quality of target groundfish species in gillnet catches (Rafferty et al., 2012).

In this study, we addressed the question of whether recent increases in spiny dogfish abundance, as identified by fishermen (Tallack and Mandelman, 2009), have resulted from increased availability of the spiny dogfish stock to major fisheries. Examination of $S O_{\mathrm{C}}$ revealed
2 periods of contrasting overlap during autumn: 1) a low period before 1998 during which spiny dogfish were infrequently caught in both fisheries and the bottom trawl survey and 2) a high period, thereafter, reflecting a greater area where spiny dogfish were captured by the survey crew and each fishery. Interestingly, the year separating the 2 distinct periods, 1998, was also the year in which the stock was declared overfished 


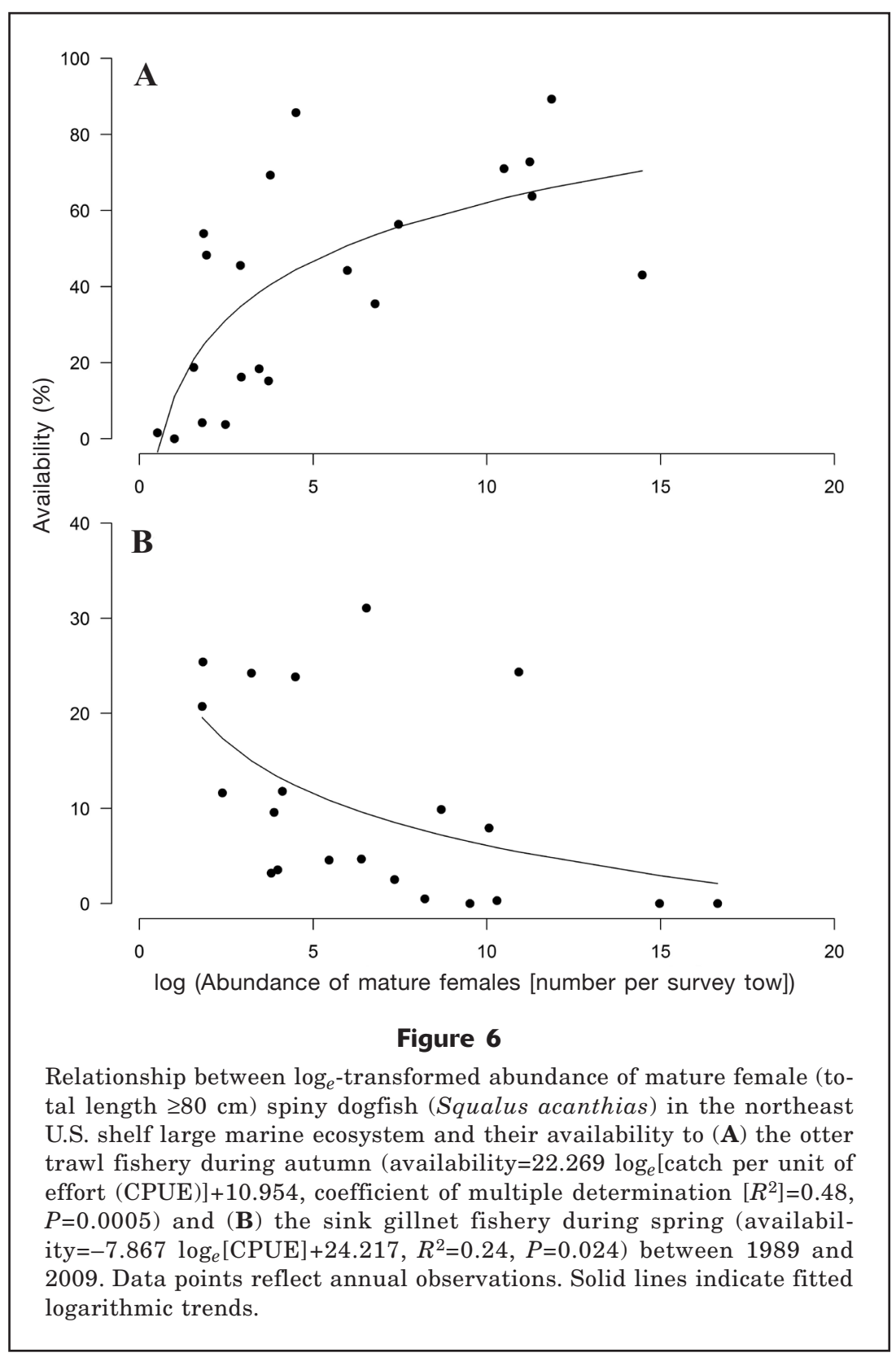

$\left(\mathrm{ASMFC}^{2}\right)$. Higher spatial overlap after 1998 indicates increased availability of the stock to each fishery. Although this observation seems counterintuitive given that the fishery in the 2000s was strictly one of bycatch, it is possible that this increased overlap is related to distributions of species targeted by fisheries and spiny dogfish (i.e., predation).

The use of commercial statistics in tracking abundance trends is often discouraged because of nonrandom fishery behavior, particularly because fishing crews search for concentrations of fish rather than fish at random (Paloheimo and Dickie, 1964; Salthaug and Aanes, 2003); however, fishery-dependent data have provided a rare opportunity to examine fishery behavior and investigate how fisheries are distributed with respect to a marine resource. Clustering of spiny dogfish CPUE in the SGN fishery indicated that this fishery, compared with the OT fishery, targeted spiny dogfish more directly. Annual Moran's I values revealed relatively high clustering of CPUE during the 1990s as fishing effort spread inshore in SNE and Mid-Atlantic Bight. During this same time period, a shoreward shift in distribution, predominantly of mature males but also of mature females, was documented by the bottom trawl survey $\left(\mathrm{NEFSC}^{3}\right)$. Trends for the OT fishery indicated more random catches of spiny dogfish compared with trends for the SGN fishery, supporting the notion that OT catches are likely bycatch. Further 
support was provided by the lower percentage of catch retained by the OT fishery (autumn: 8\%; spring: $5 \%$ ) than by the SGN fishery (autumn: 61\%; spring: $81 \%$ ). The observed fishing patterns for the OT fishery likely are linked to target species distributions rather than to spiny dogfish distribution.

For the spatial analyses presented here, we relied on numerous assumptions. Trends within NEFOP data were assumed to represent those of domestic fishing fleets since 1989. This time period encompassed the development of the directed domestic fishery (1990), its collapse (late 1990s), and the onset of recovery (late 2000s). For analyses of spatial overlap of spiny dogfish distribution and fishery effort and catch, we assumed that the selected grid cell size was appropriate for both the rasterization and interpolation of station data. In contrast with our grid cell size, grid sizes of much smaller sizes (185-261 $\mathrm{km}^{2}$ ) have been used in other distributional studies in which the same fisheryindependent data set within the same geographic region have been analyzed (Methratta and Link, 2007; Nye et al., 2009). For spatial overlap analyses, results were not available on a stage-specific basis because of limited reporting of sex within fisheries data. Further investigation of interactions of spiny dogfish and fisheries at the level of life-history stages could provide insight into stage-dependent availability, elucidating the potential relationship between fishermen and spawning stock biomass (i.e., mature female abundance), mature male biomass (i.e., alternative harvest by way of a male-selective fishery), and recruitment (i.e., neonate abundance).

\section{Acknowledgments}

The authors thank all those individuals who have worked or volunteered aboard the NOAA Ships Albatross IV and Henry B. Bigelow, Woods Hole, Massachusetts, for assistance with survey data collection. In addition, special thanks are extended to those observers who collected the NEFOP data and all fishermen who participated within NEFOP. This project was funded by the Sea Grant Fellowship in Population Dynamics of the National Marine Fisheries Service.

\section{Literature cited}

Aglen, A., A. Engås, I. Huse, K. Michalsen, and B. K. Stensholt. 1999. How vertical fish distribution may affect survey results. ICES J. Mar. Sci. 56:345-360. Article

Anderson, M. J.

2001. A new method for non-parametric multivariate analysis of variance. Austral Ecol. 26:32-46. Article

2005. PERMANOVA: a FORTRAN computer program for permutational multivariate analysis of variance, $24 \mathrm{p}$. Dept. Statistics, Univ. Auckland, New Zealand.

Arreguín-Sánchez, F.

1996. Catchability: a key parameter for fish stock assessment. Rev. Fish Biol. Fish. 6:221-242. Article
Azarovitz, T. R.

1981. A brief historical review of the Woods Hole laboratory trawl survey time series. Can. Spec. Publ. Fish. Aquat. Sci. 58:62-67.

Bertrand, S., E. Díaz, and M. Ñiquen.

2004. Interactions between fish and fisher's spatial distribution and behaviour: an empirical study of the anchovy (Engraulis ringens) fishery of Peru. ICES J. Mar. Sci. 61:1127-1136. Article

Bivand, R., M. Altman, L. Anselin, R. Assução, O. Berke, A. Bernat, G. Blanchet, E. Blankmeyer, M. Carvalho, B. Christensen, Y. Chun, C. Dormann, S. Dray, V. Gómez-Rubio, R. Halbersma, E. Krainski, P. Legendre, N. Lewin-Koh, H. Li, J. Ma, G. Millo, W. Mueller, H. Ono, P. Peres-Neto, G. Piras, M. Reder, M. Tiefelsdorf, and D. Yu.

2012. spdep: spatial dependence: weighting schemes, statistics, and models. R package; vers. 0.5-46. [Available from http://cran.r-project.org/web/packages/spdep/ index.html.]

Brodeur, R. D., C. L. Suchman, D. C. Reese, T. W. Miller, and E. A. Daly.

2008. Spatial overlap and trophic interactions between pelagic fish and large jellyfish in the northern California Current. Mar. Biol. 154:649-659. Article

Camhi, M

1998. Sharks on the Line: a state-by-state analysis of sharks and their fisheries, 158 p. National Audubon Society, Islip, NY.

Carlson, A. E., E. R. Hoffmayer, C. A. Tribuzio, and J. A. Sulikowski.

2014. The use of satellite tags to redefine movement patterns of spiny dogfish (Squalus acanthias) along the U.S. East Coast: implications for fisheries management. PLoS ONE 9(7):e103384. Article

Chosid, D. M., M. Pol, M. Szymanski, F. Mirarchi, and A. Mirarchi.

2012. Development and observations of a spiny dogfish Squalus acanthias reduction device in a raised footrope silver hake Merluccius bilinearis trawl. Fish. Res. 114:66-75. Article

Crawley, M. J.

2007. The R book, 950 p. John Wiley \& Sons Ltd., Chichester, UK.

Cressie, N. A. C.

1993. Statistics for spatial data, rev. ed., 928 p. Wiley, New York.

Francis, R. I. C. C., R. J. Hurst, and J. A. Renwick.

2003. Quantifying annual variation in catchability for commercial and research fishing. Fish. Bull. 101:293-304.

Fréon, P., F. Gerlotto, and O. A. Misund.

1993. Consequences of fish behaviour for stock assessment. ICES Mar. Sci. Symp. 196:190-195.

Frisk, M. G., D. E. Duplisea, and V. M. Trenkel.

2011. Exploring the abundance-occupancy relationships for the Georges Bank finfish and shellfish community from 1963 to 2006. Ecol. Appl. 21:227-240. Article

Godø, O. R.

1994. Factors affecting the reliability of groundfish abundance estimates from bottom trawl surveys. In Marine fish behaviour in capture and abundance estimation (A. Fernö and S. Olsen, eds.), p. 166-195. Fishing News Books, Oxford, UK.

Godø, O. R., S. J. Walsh, and A. Engås.

1999. Investigating density-dependent catchability in bottom-trawl surveys. ICES J. Mar. Sci. 56:292-298 Article 
Goodchild, M. F.

1986. Spatial Autocorrelation, 56 p. Geo Books, Norwich, UK.

Harley, S. J., and R. A. Myers.

2001. Hierarchical Bayesian models of length-specific catchability of research trawl surveys. Can. J. Fish. Aquat. Sci. 58:1569-1584. Article

Hijmans, R. J., J. van Etten, M. Mattiuzzi, M. Sumner, J. A. Greenberg, O. P. Lamigueiro, A. Bevan, E. B. Racine, and A. Shortridge.

2012. Raster: geographic analysis and modeling with raster data. $\mathrm{R}$ package; vers. 2.0-05. [Available from http://cran.r-project.org/web/packages/raster/index. html.]

Hilborn, R.

2007. Managing fisheries is managing people: what has been learned? Fish Fish. 8:285-296. Article

Hilborn, R., and C. J. Walters. (eds.)

1992. Quantitative fisheries stock assessment: choice, dynamics and uncertainty, 570 p. Chapman and Hall, New York.

Hutchings, J. A.

1996. Spatial and temporal variation in the density of northern cod and a review of hypotheses for the stock's collapse. Can. J. Fish. Aquat. Sci. 53:943-962. Article

MacCall, A. D.

1990. Dynamic geography of marine fish populations, 153 p. Univ. Washington Press, Seattle, WA.

Mandelman, J. W., and M. A. Farrington.

2007. The estimated short-term discard mortality of a trawled elasmobranch, the spiny dogfish (Squalus acanthias). Fish. Res. 83:238-245. Article

Marino, M. C., II, F. Juanes, and K. D. E. Stokesbury.

2009. Spatio-temporal variations of sea star Asterias spp. distributions between sea scallop Placopecten magellanicus beds on Georges Bank. Mar. Ecol. Prog. Ser. 382:59-68. Article

Matheron, G.

1971. The theory of regionalized variables and its applications, 211 p. École Nationale Supérieure des Mines de Paris, Paris.

Methot, R. D., Jr., and C. R. Wetzel.

2013. Stock synthesis: a biological and statistical framework for fish stock assessment and fishery management. Fish. Res. 142:86-99. Article

Methratta, E. T., and J. S. Link.

2007. Ontogenetic variation in habitat association for four groundfish species in the Gulf of Maine-Georges Bank region. Mar. Ecol. Prog. Ser. 338:169-181. Article

Michalsen, K., O. R. Godø, and A. Fernö.

1996. Diel variation in the catchability of gadoids and its influence on the reliability of abundance indices. ICES J. Mar. Sci. 53:389-395. Article

Moran, P. A. P.

1948. The interpretation of statistical maps. J. R. Stat. Soc. B 10:243-251.

Murawski, S. A., K. Mays, and D. Christensen.

1995. Fishery observer program. In Status of fishery resources off the Northeastern United States for 1994. NOAA Tech. Memo. NMFS-NE-108, p. 35-41.

Musick, J. A.

1999. Ecology and conservation of long-lived marine animals. Am. Fish. Soc. Symp. 23:1-10.

Nammack, M. F., J. A. Musick, and J. A. Colvocoresses.

1985. Life history of spiny dogfish off the northeastern United States. Trans. Am. Fish. Soc. 114:367-376.
Nielsen, J. K., S. J. Taggart, T. C. Shirley, and J. Mondragon. 2007. Spatial distribution of juvenile and adult female Tanner crabs (Chionoecetes bairdi) in a glacial fjord ecosystem: implications for recruitment processes. ICES J. Mar. Sci. 64:1772-1784. Article

Nye, J. A., J. S. Link, J. A. Hare, and W. J. Overholtz. 2009. Changing spatial distribution of fish stocks in relation to climate and population size on the Northeast United States continental shelf. Mar. Ecol. Prog. Ser. 393:111-129. Article

O'Connell, C. P., P. He, J. Joyce, E. M. Stroud, and P. H. Rice. 2012. Effects of the SMART ${ }^{\mathrm{TM}}$ (Selective Magnetic and Repellent-Treated) hook on spiny dogfish catch in a longline experiment in the Gulf of Maine. Ocean Coast. Manage. 97:38-43. Article

Oliver, M. A., and R. Webster.

1990. Kriging: a method of interpolation for geographical information systems. Int. J. Geogr. Inf. Syst. 4:313-332. Article

Paloheimo, J. E., and L. M. Dickie.

1964. Abundance and fishing success. Rapp. p.-v. Reun. (Dan.) 155:152-163.

Park, Y.-L., and J. J. Obrycki.

2004. Spatio-temporal distribution of corn leaf aphids (Homoptera: Aphididae) and lady beetles (Coleoptera: Coccinellidae) in Iowa cornfields. Biol. Control 31:210-217. Article

Pebesma, E. J.

2004. Multivariable geostatistics in S: the gstat package. Comput. Geosci. 30:683-691. Article

Pennington, M., and O. R. Godø.

1995. Measuring the effect of changes in catchability on the variance of marine survey abundance indices. Fish. Res. 23:301-310. Article

Quinn, G. P., and M. J. Keough.

2002. Experimental design and data analysis for biologists, 553 p. Cambridge Univ. Press, Cambridge, UK.

Rafferty, A. R., E. O. Brazer Jr., and R. D. Reina.

2012. Depredation by harbor seal and spiny dogfish in a Georges Bank gillnet fishery. Fish. Manage. Ecol. 19:264-272. Article

Rago, P. J.

2005. Fishery independent sampling: survey techniques and data. In Management techniques for elasmobranch fisheries (J. A. Musick and R. Bonfil, eds.), p. 201-215. FAO Fish, Tech. Pap. 474, Rome. [Available at http://www.fao.org/docrep/009/a0212e/A0212E16. htm.]

Rago, P. J., and K. A. Sosebee.

2009. The agony of recovery: scientific challenges of spiny dogfish recovery programs. In Biology and management of dogfish sharks (V. F. Gallucci, G. A. McFarlane, and G. G. Bargmann, eds.), p. 343-372. Am. Fish. Soc., Bethesda, MD.

Rago, P. J., K. A. Sosebee, J. K. T. Brodziak, S. A. Murawski, and E. D. Anderson.

1998. Implications of recent increases in catches on the dynamics of Northwest Atlantic spiny dogfish (Squalus acanthias). Fish. Res. 39:165-181. Article

$\mathrm{R}$ Development Core Team.

2011. R: a language and environment for statistical computing. R Foundation for Statistical Computing, Vienna, Austria. [Available from http://www.r-project.org/ accessed November 2011.] 
Reese, D. C., and R. D. Brodeur.

2006. Identifying and characterizing biological hotspots in the northern California Current. Deep Sea Res. (II Top. Stud. Oceanogr.) 53:291-314. Article

Rose, G. A., B. A. Atkinson, J. Baird, C. A. Bishop, and D. W. Kulka.

1994. Changes in distribution of Atlantic cod and thermal variations in Newfoundland waters, 19801992. ICES Mar. Sci. Symp. 198:542-552.

Rose, G. A., and D. W. Kulka.

1999. Hyperaggregation of fish and fisheries: how catch-per-unit-effort increased as the northern cod (Gadus morhua) declined. Can. J. Fish. Aquat. Sci. 56:118-127. Article

Rulifson, R. A., and T. M. Moore.

2009. Population estimates of spiny dogfish aggregations overwintering south of Cape Hatteras, North Carolina, using an area density method. In Biology and management of dogfish sharks (V. F. Gallucci, G. A. McFarlane, and G. G. Bargmann, eds.) p. 133-138. Am. Fish. Soc., Bethesda, MD.

Sagarese, S. R., M. G. Frisk, R. M. Cerrato, K. A. Sosebee, J. A. Musick, and P. J. Rago.

2014a. Application of generalized additive models to examine ontogenetic and seasonal distributions of spiny dogfish (Squalus acanthias) in the Northeast (US) shelf large marine ecosystem. Can. J. Fish. Aquat. Sci. 71:847-877. Article

Sagarese, S. R., M. G. Frisk, T. J. Miller, K. A. Sosebee, J. A. Musick, and P. J. Rago.

2014b. Influence of environmental, spatial, and ontogenetic variables on habitat selection and management of spiny dogfish in the Northeast (US) shelf large marine ecosystem. Can. J. Fish. Aquat. Sci. 71:567-580. Article

Salthaug, A., and S. Aanes.

2003. Catchability and the spatial distribution of fishing vessels. Can. J. Fish. Aquat. Sci. 60:259-268. Article

Shepherd, T., F. Page, and B. Macdonald.

2002. Length and sex-specific associations between spiny

\section{Appendix: Semivariograms}

Spatial analyses of spatiotemporal overlap between spiny dogfish (Squalus acanthias) and commercial fisheries in the northeast U.S. shelf large marine ecosystem included the use of semivariograms to investigate the spatial dependence of sample points, enabling geostatistical modeling. Semivariograms were used in conjunction with ordinary kriging to interpolate survey and fishery catch of spiny dogfish outside of the sampled domain. This appendix provides details on the semivariogram modeling used and model selection process in this study of spatiotemporal interactions between spiny dogfish and commercial fisheries.

\section{Methods}

Empirical semivariograms $(\gamma[h])$ were calculated with the following semivariance equation: dogfish (Squalus acanthias) and hydrographic variables in the Bay of Fundy and Scotian Shelf. Fish. Oceanogr. 11:78-89. Article

Smith, S. J., and F. H. Page.

1996. Associations between Atlantic cod (Gadus morhua) and hydrographic variables: implications for the management of the $4 \mathrm{VsW}$ cod stock. ICES J. Mar. Sci. 53:597-614. Article

Swain, D. P., G. A. Poirier, and A. F. Sinclair.

2000. Effect of water temperature on catchability of Atlantic cod (Gadus morhua) to the bottom-trawl survey in the southern Gulf of St Lawrence. ICES J. Mar. Sci. 57:56-68. Article

Tallack, S. M. L., and J. W. Mandelman.

2009. Do rare-earth metals deter spiny dogfish? A feasibility study on the use of electropositive "mischmetal" to reduce the bycatch of Squalus acanthias by hook gear in the Gulf of Maine. ICES J. Mar. Sci. 66:315-322. Article

Trenkel, V. M., R. I. C. C. Francis, P. Lorance, S. Mahévas, M.-

J. Rochet, and D. M. Tracey.

2004. Availability of deep-water fish to trawling and visual observation from a remotely operated vehicle (ROV). Mar. Ecol. Prog. Ser. 284:293-303. Article

Wagenmakers, E. J., and S. Farrell.

2004. AIC model selection using Akaike weights. Psychon. Bull. Rev. 11:192-196. Article

Waring G. T., E. Josephson, K. Maze-Foley, and P. E. Rosel (eds.).

2011. U.S. Atlantic and Gulf of Mexico marine mammal stock assessments-2010, Appendix III. NOAA Tech. Memo. NMFS-NE-219, 595 p.

Webster, R., and A. B. McBratney.

1989. On the Akaike Information Criterion for choosing models for variograms of soil properties. J. Soil Sci. 40:493-496. Article

Wilberg, M. J., J. T. Thorson, B. C. Linton, and J. Berkson.

2009. Incorporating time-varying catchability into population dynamic stock assessment models. Rev. Fish. Sci. 18:7-24. Article

$$
\gamma(h)=\frac{1}{2 n(h)} \Sigma\left[Z\left(x_{\mathrm{i}}\right)-Z\left(x_{\mathrm{i}+\mathrm{h}}\right)\right]^{2},
$$

where $Z\left(x_{\mathrm{i}}\right)$ and $Z\left(x_{\mathrm{i}+\mathrm{h}}\right)=$ measured values of catch per unit of effort (CPUE) at sample points $x_{i}$ and $x_{\mathrm{i}+\mathrm{h}}$, respectively; and

$n(h)=$ the total number of sample pairs for any separation distance $h$ (Matheron, 1971).

Each semivariogram was used to estimate 3 parameters: 1$)$ the range $(a)$, or the asymptotic distance beyond which samples were spatially independent; 2) the sill $\left(C_{\mathrm{S}}\right)$, or the value of the semivariance at any distance $\geq a$; and 3 ) the nugget $\left(C_{0}\right)$, the semivariance at the origin $(h=0)$. In situations where autocorrelation between 2 locations changed with both direction and distance (a condition known as anisotropy), 2 additional parameters were estimated: 1) the ratio of the minor to major axis lengths and 2) the angle of the principal direction of continuity (Pebesma et al., 2011). Anisotropic parameters were estimated with the use of the intamap package (Pebesma et al., 2011). Multiple theoretical models were tested, including the following ones: 


\begin{tabular}{|c|c|c|c|c|c|c|c|c|c|}
\hline \multicolumn{10}{|c|}{ Appendix Table } \\
\hline \multicolumn{10}{|c|}{$\begin{array}{l}\text { Model selection criteria used to identify optimal semivariogram models for spiny dogfish (Squalus acanthias) catch } \\
\text { per unit effort in the northeast U.S. shelf large marine ecosystem between } 1989 \text { and } 2009 \text { for the sink gillnet (SGN) } \\
\text { fishery, otter trawl (OT) fishery, and Northeast Fisheries Science Center bottom trawl survey (Survey). Model types } \\
\text { include nugget (Nug), exponential (Exp), Gaussian (Gau), and spherical (Sph). AIC=Akaike's information criterion; } \\
\Delta \text { AIC=difference in AIC with respect to the AIC of the best candidate model; wAIC=model weights. }\end{array}$} \\
\hline & & \multicolumn{4}{|c|}{ Autumn } & \multicolumn{4}{|c|}{ Spring } \\
\hline & & Nug & Exp & Gau & Sph & Nug & Exp & Gau & Sph \\
\hline \multirow[t]{3}{*}{ SGN } & $\mathrm{AIC}$ & 283.3 & 255.1 & 304.1 & 257.0 & 284.6 & 245.0 & 231.7 & 242.5 \\
\hline & $\Delta \mathrm{AIC}$ & 28.3 & 0.0 & 49.0 & 1.9 & 52.9 & 13.3 & 0.0 & 10.8 \\
\hline & wAIC & 0.0 & 72.3 & 0.0 & 27.7 & 0.0 & 0.1 & 99.4 & 0.5 \\
\hline \multirow[t]{3}{*}{$\mathrm{OT}$} & AIC & 315.0 & 265.1 & 263.5 & 263.8 & 283.3 & 254.7 & 262.9 & 254.8 \\
\hline & $\Delta \mathrm{AIC}$ & 51.5 & 1.6 & 0.0 & 0.4 & 28.6 & 0.0 & 8.3 & 0.1 \\
\hline & wAIC & 0.0 & 19.8 & 43.8 & 36.4 & 0.0 & 50.9 & 0.8 & 48.3 \\
\hline \multirow[t]{3}{*}{ Survey } & AIC & 263.8 & 181.1 & 215.1 & 205.8 & 273.6 & 209.7 & 289.2 & 208.2 \\
\hline & $\Delta \mathrm{AIC}$ & 82.6 & 0.0 & 34.0 & 24.7 & 65.4 & 1.5 & 81.0 & 0.0 \\
\hline & wAIC & 0.0 & 100.0 & 0.0 & 0.0 & 0.0 & 32.2 & 0.0 & 67.8 \\
\hline
\end{tabular}

Nugget: $\quad \gamma(h)=C_{0}=C_{\mathrm{S}}$;

Gaussian: $\gamma(h)=C_{0}+\left(C_{\mathrm{S}}-C_{0}\right) \times\left[1-\exp \left(-\frac{h^{2}}{a^{2}}\right)\right]$;

Exponential: $\gamma(h)=C_{0}+\left(C_{\mathrm{S}}-C_{0}\right) \times\left[1-\exp \left(-\frac{h}{a}\right)\right]$;

$\begin{array}{ll} & \gamma(h)=C_{0}+\left(C_{\mathrm{S}}-C_{0}\right) \\ \text { Spherical: } & \times\left[1.5 \times\left(\frac{h}{a}\right)-0.5 \times\left(\frac{h}{a}\right)^{3}\right]\end{array}$

Optimal semivariogram models were selected on the basis of the lowest Akaike's information criterion (AIC) calculated with the following equation:

$$
A I C=n \ln (R)+2 p,
$$

where $n=$ the number of experimental points on the semivariogram;

$R=$ the residual sum of squares; and

$p=$ the number of parameters in the model (Webster and McBratney, 1989).

AIC values also were reported in terms of delta $(\Delta) \mathrm{AIC}$, which represents the difference in AIC with respect to the AIC of the best candidate model $\left(\Delta \mathrm{AIC}_{\mathrm{i}}=\mathrm{AIC}_{\mathrm{i}}-\right.$ minimum AIC), and weights to determine conditional probabilities of each model configuration (Wagenmakers and Farrell, 2004).

\section{Results}

Optimal semivariogram models for each of 2 major commercial fisheries, the sink gillnet (SGN) fishery and the otter trawl (OT) fishery, and the Northeast Fisheries Science Center bottom trawl survey incorporated anisotropy and varied seasonally in structure (see Table 2 in the main article). For the SGN fishery, the spatial correlation of spiny dogfish CPUE was best fitted by an exponential model during autumn and a Gaussian model during spring (Appdx. Table 1). For the OT fishery, Gaussian and exponential models were selected for autumn and spring, respectively. The spatial correlation of spiny dogfish CPUE for the survey was best fitted by exponential and spherical models during autumn and spring, respectively. Overall, optimal semivariogram models were at least adequate in capturing the overall trend indicated by the sample semivariograms (Appdx. Fig. 1).

\section{Literature cited}

Matheron, G.

1971. The theory of regionalized variables and its applications, 211 p. École Nationale Supérieure des Mines de Paris, Paris.

Pebesma E., D. Cornford, G. Dubois, G. B. M. Heuvelink, D.

Hristopulos, J. Pilz, U. Stöhlker, G. Morin, and J. O. Skøien. 2011. INTAMAP: the design and implementation of an interoperable automated interpolation web service. Comput. Geosci. 37:343-352. Article

Wagenmakers, E. J., and S. Farrell.

2004. AIC model selection using Akaike weights. Psychon. Bull. Rev. 11:192-196. Article

Webster, R., and A. B. McBratney.

1989. On the Akaike Information Criterion for choosing models for variograms of soil properties. J. Soil Sci. 40:493-496. Article 


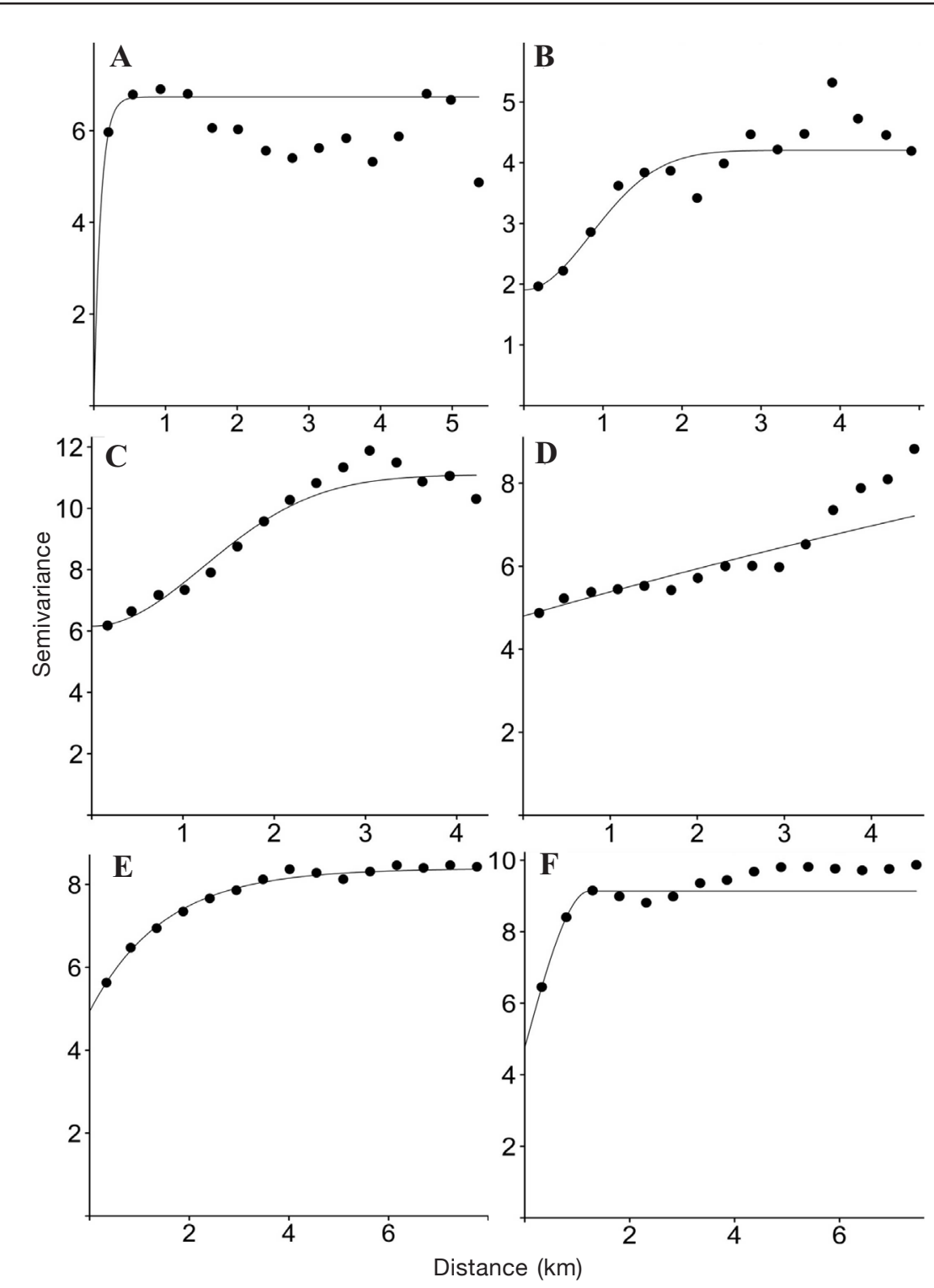

Appendix Figure

Sample and fitted semivariograms of spiny dogfish (Squalus acanthias) catch per unit effort in the northeast U.S. shelf large marine ecosystem between 1989 and 2009 for the sink gillnet fishery in (A) autumn and (B) spring, the otter trawl fishery in (C) autumn and (D) spring, and the Northeast Fisheries Science Center bottom trawl survey in (E) autumn and (F) spring. Note that ranges on $\mathrm{x}$ - and $\mathrm{y}$-axes differ between panels. 